\title{
The Choice of Interactive Control Systems under Different Innovation Management Modes
}

\author{
Josep Bisbe and Ricardo Malagueño
}

ESADE Business School, Universitat Ramon Llull

Av. Pedralbes, 60-62

08034 Barcelona (Spain)

Tel: 34932806162

Fax: 34932048105

josep.bisbe@esade.edu 


\title{
The Choice of Interactive Control Systems under Different Innovation Management Modes
}

\begin{abstract}
This paper contributes to the recent levers of control (LOC) literature on the relationships between innovation and management accounting and control systems (MACS) by emphasising the importance of the choice by which individual MACS are selected for interactive use. Using data from a survey-based study on innovation and control practices in 57 medium-sized Spanish firms, we find evidence supporting that 1) the choice of individual MACS selected for interactive use is associated to a firm's innovation management mode (IMM), and 2) the level of product innovation output is influenced by whether or not IMM and interactive MACS present similar cognitive models and whether the sophistication of the information contents provided by the interactive MACS responds to the priority needs perceived in the IMM. Our findings further indicate that similarity in patterns between IMM and MACS does not lead to a beneficial impact on the level of innovation outputs, suggesting instead that it may induce the replication of dysfunctional existing trends caused by strategic momentum regarding innovation.
\end{abstract}

Keywords: control systems, management accounting, levers of control, interactive use, innovation.

\section{Introduction}

The relationships between formal management accounting and control systems (MACS) and innovation have been the object of increasing interest in a recent stream of literature. In contrast to traditional views, a growing number of studies have concluded that formal MACS may effectively contribute to the innovation effort provided that certain conditions are met (e.g. Simons, 1995; Chapman, 1998; Davila 2000, 2005; Cardinal, 2001; Ditillo, 2004; Bonner, 2005; Granlund and Taipaleenmaki, 2005; Davila et al., 2005, 2008; Langfield-Smith, 2007). Several of these studies have highlighted the relevance of the attributes of use of MACS in supporting creative innovation (Simons, 1995; Chapman, 1998; Ahrens and Chapman, 2004). This line of research argues that, under some styles of use, formal MACS may be dynamic, flexible and adaptive to changing environments, while at the same time they are stable enough to frame cognitive models and communication patterns (Davila, 2005). One of the frameworks that has incorporated differences in styles of use of formal MACS is Simons' levers of control framework (LOC) (Simons, 1995, 2000), which asserts that the joint use and integration between several levers (namely belief systems, boundary systems, diagnostic systems and interactive systems) enacts a dynamic tension between formal MACS, thereby allowing firms 
to encourage innovation while concurrently pursuing pre-established rules and plans. Drawing on the LOC framework, some researchers have empirically investigated the interplay between levers (Tuomela, 2005; Henri, 2006; Widener, 2007) while others have provided in-depth insights on the features and separate effects of the various individual levers. Within the latter group, special attention has been paid to interactive control systems (ICS) (e.g. Abernethy and Brownell, 1999; Bonner et al., 2002; Bisbe and Otley, 2004; Naranjo-Gil and Hartmann, 2007). Despite this interest, little emphasis has yet been placed on the organisational factors that influence the choice of which are the individual MACS selected by firms for interactive use (hereafter used interchangeably with ICS) nor on the implications of that choice.

Building on Simons (1991), we argue in this paper that the choice of ICS, largely ignored in prior LOC literature, is relevant and deserves further attention. According to LOC theory, a given firm purposefully chooses a very limited number of individual MACS for interactive use (often only one) (Simons, 1991; 2000, p. 224). Connecting arguments derived from cognitive theories (Howells, 1995; Smith et al., 2005; Bergman et al., 2007; Birnberg et al., 2007) with arguments related to the ability of MACS to mitigate the dysfunctional excesses of strategic momentum (Miller and Friesen, 1982; Amburgey and Miner, 1992; Jansen, 2004) we consider it plausible that not all choices of ICS are equally pertinent, which will have consequences for organisational outcomes such as innovation. Consequently, we claim that better understanding the systematic factors associated with these choices as well as the implications of these choices is of relevance to both researchers and managers. Hence, the purpose of this paper is two-fold. First, it aims to examine whether systematic organisational factors cause top managers to make different choices as to which individual MACS are selected for interactive use. More specifically, we explore the links between the configurations of the organisational and managerial processes by which innovation arises (i.e. the innovation management modes, IMM) (Roussel et al., 1991; Park and Kim, 2005) and the choice of ICS. 
We express these links in terms of expected patterns of fit between individual MACS selected for interactive use and specific IMM. Second, this paper aims to investigate whether this expected fit is effectively translated into beneficial implications on product innovation outputs.

This study contributes to the emerging literature on the LOC framework by focusing not on the effects (separately or in interplay with other levers) of any individual MACS (whichever this may be) being used interactively, but on issues related to the choice as to which individual MACS is the one to be used interactively. In this regard, more precisely, we aim to contribute in at least three respects. First, and in contrast to most previous studies on ICS, the object of analysis of this paper explicitly covers several distinct individual MACS which are candidates for interactive use (namely budget systems, balanced scorecards and project management systems), thus obtaining insights regarding their idiosyncrasies and their suitability for interactive use in specific settings. Second, we extend Simons' (1991) postulate affirming that the choice of the interactive MACS is associated to attributes of the competitive setting, to attributes related to internal configurations of organisational and managerial processes such as IMM. Results obtained from survey responses from 57 medium-sized firms provide evidence supporting that the choice of ICS is associated to the IMM followed by firms. Third, this study introduces a new angle in the discussion concerning the effects of ICS on innovation. Previous literature has investigated these effects disregarding the pertinence of the choice of the individual MACS selected for interactive use (e.g. Bonner et al., 2002; Bisbe and Otley, 2004; Henri, 2006; Widener, 2007). In this paper, we address the implications of this choice on product innovation outputs. Our empirical results support that fit in terms of similar characteristics between the individual MACS selected for interactive use and the firm's IMM influences the level of product innovation outputs. However, our results suggest that similar patterns between ICS and IMM do not necessarily conduce to beneficial implications (Miller and Friesen, 1982; Bisbe and Otley, 2004) but may induce instead to replication of, and 
conformity to, dysfunctional existing trends. Based on this finding, we introduce a distinction between supplementary and complementary fit (Cable and Edwards, 2004) which we believe may be useful for future MACS research.

The remainder of the paper is organised as follows. Section 2 outlines the conceptual underpinnings of this study, introducing ICS within the LOC framework, the choice of individual MACS as ICS and the configurations of IMM. Section 3 presents a series of testable propositions derived from this conceptual background. Section 4 describes the research design, including data collection procedures and operationalisation of measurement instruments. The results of the study are presented in Section 5. We conclude in Section 6 by discussing the implications of the study, evaluating its limitations and summarising its findings.

\section{Conceptual background}

\section{The interactive use of control systems and its influence on innovation}

Management Accounting and Control Systems (MACS) refer to the set of procedures and processes that managers use in order to provide valuable information in decision-making, planning, monitoring and evaluation and, ultimately, to ensure the achievement of their goals and the goals of their organizations. MACS comprise multiple formal and informal individual control systems that operate collectively and interdependently to constitute control packages (Otley, 1980, 1999; Chiapello, 1996; Merchant and Otley, 2007; Malmi and Brown, 2008). The LOC framework (Simons, 1995, 2000) has highlighted the role of packages of formal MACS in coping with and taking advantage of firms' inherent tension between the need for creative innovation and the need for the predictable achievement of pre-established goals. According to LOC theory, this is achieved through the interplay of four levers of control (belief systems, boundary systems, diagnostic systems and interactive systems) which act as forces that operate 
in different directions and collectively create in turn a corresponding dynamic tension within the overall control package.

Developing the LOC framework, an emerging stream of empirical research has investigated the joint use and integration between levers from different angles such as the implications of some levers on the features of others (Tuomela, 2005; Chenhall et al., 2008), the effects of the interplay between levers on outcomes (Henri, 2006) or the multiple interdependencies among the levers of control and their implications for outcomes (Widener, 2007). Complementary to the insights on the integration between levers, some studies have focused on providing an in-depth understanding of the features and separate effects of the various individual levers. Given the relative conceptual novelty of interactive control systems (ICS) and their expected role in encouraging innovative behaviour (Simons, 1995, 2000), it is not surprising that they have been warranted special interest in recent empirical research on innovation and strategic change (e.g. Abernethy and Brownell, 1999; Bonner et al., 2002; Bisbe and Otley, 2004; Henri, 2006; Naranjo-Gil and Hartmann, 2007; Heidmann, 2008).

ICS are formal information systems used by managers to personally involve themselves in the decision activities of subordinates, to discuss strategic uncertainties and to foster dialogue and debate. ${ }^{1}$ They expand and orientate opportunity-seeking and provide input to the formation of emergent strategies. Thus, and in interplay with the other levers of control, ICS eventually contribute to fostering the development of innovation initiatives that are successfully transformed into enhanced performance (Simons, 1995, 2000). Several empirical studies have investigated the (direct) relationships between ICS and an array of organisational variables related to innovation, including attributes of new product development projects (NPD), strategic capabilities such as organisational learning and innovativeness (i.e. the attitudinal openness of the organization to new ideas, products and processes), as well as product innovation outputs. Hence, and in contrast to the LOC framework's theoretical claim, the 
empirical findings of Bonner et al. (2002) suggest that the use of ICS during NPD may in fact constrain creativity and impede progress towards successful innovation outputs. However, other research has found evidence in favour of a positive direct effect of ICS on organisational learning and innovativeness (e.g. Henri, 2006) and on strategic change (e.g. Abernethy and Brownell, 1999; Naranjo-Gil and Hartmann, 2007). In her study on the interplay between levers of control and learning, Widener (2007) did not find a direct link between ICS and learning, but, rather, an indirect influence primarily channelled through diagnostic systems. Some studies have claimed that the relationship between control systems and innovation output may not be uniformly linear across the spectrum of innovation. For example, Bisbe and Otley (2004) argued that, in the case of high-innovating firms, ICS contribute to reducing the risk of excessive or inadequate innovation and are, therefore, associated with a decrease in the level of innovation output; while in the case of low-innovating firms, ICS may contribute to overcoming organisational complacency, so that, eventually, they are likely to be associated with increased innovation. Overall, even though prior LOC literature supports the postulate that ICS play a significant role in shaping innovation, there is still a lack of consensus on the specific nature of this relationship. ${ }^{2}$

\section{The choice of interactive control systems}

One plausible explanation for this lack of consensus is the limited attention in prior research to aspects related to the choice of individual formal MACS to be selected for interactive use. However, this limited attention is unwarranted since the choice of ICS is a crucial aspect of the LOC framework. LOC theory suggests it is most likely that, in a given firm, some of the individual formal MACS are used diagnostically, while others are used interactively. Attempting to use all or many of the individual MACS interactively for extended periods of time would risk creating a situation of information overload, superficial analysis, a lack of perspective and potential paralysis (Simons, 1991, p. 59). Therefore, except in situations where 
a clear strategic vision is lacking and during short periods of crisis, top managers introduce interactivity within the control package through the deliberate choice of a very limited number of individual MACS to be used interactively (most often, only one) (Simons, 2000, p. 223). ${ }^{3}$

Any individual formal MACS is a potential candidate for interactive use (Simons, 2000, p. 219). However, the choice of which individual MACS is selected for interactive use is neither universal nor inconsequential, since each individual MACS has idiosyncratic informational effects. Informational effects of individual MACS are twofold (Birnberg et al., 2007). On the one hand, individual MACS provide information contents with different levels of sophistication (Tillema, 2005) in terms of attributes such as scope, aggregation and integration (Chenhall and Morris, 1986; Bouwens and Abernethy, 2000). ${ }^{4}$ On the other hand, each individual MACS has a different influence on how boundedly rational managers use heuristics to search for and process this information and how managers form and use cognitive models or mental representations of their organisations and environment (Markmann and Gettner, 2001; Birnberg et al., 2007). Since ICS focus organisational attention and set the organisational agendas (Simons, 1995, 2000), the individual MACS selected for interactive use are especially instrumental in both focusing on the information contents perceived as a priority by senior management, and in framing heuristics and cognitive models.

In this study, we focus on three individual MACS which, according to the literature, are widely used in practice (Chenhall and Langfield-Smith, 1998; Rigby, 2001; Gehrke and Horvath, 2002; Speckbacher et al., 2003; Neely et al., 2007) and are candidates for interactive use (i) budget systems (Abernethy and Brownell, 1999; Covaleski et al., 2003) (ii) performance measurement systems (Garengo et al., 2005) such as the balanced scorecard (Kaplan and Norton, 1996; 2000; Tuomela, 2005) or the tableaux-de-bord (Epstein and Manzoni, 1997; Bourguignon et al., 2004) (hereafter BSC) $)^{5}$ and (iii) project management systems (hereafter, PMS) (Davila, 2000; PMI, 2004). These three individual MACS cover different combinations 
of attributes of information contents sophistication (Van der Veeken and Wouters, 2002; Chong and Eggleton, 2003; Subramaniam and Mia, 2003; PMI, 2004). The differences in the way these three individual MACS frame information induce different managers' heuristics and cognitive representations (Birnberg et al., 2007).

Top managers appear to make different choices as to which individual MACS to use interactively and which to use diagnostically. This choice is not random, but subject to some systematic factors (Simons, 2000). Simons (1991), for example, found evidence supporting that the choice is influenced by characteristics of the strategic setting (such as technological dependence, regulation, complexity of value chain and ease of tactical response). Despite this claim, the LOC literature that has investigated which systematic factors influence the choice of the control system to be used interactively is still very sparse and has been limited to characteristics of competitive markets, ignoring the potential role of the internal organisational configurations in this respect.

\section{Typologies of $R \& D$ and innovation management}

Organisational and managerial processes of $R \& D$ and innovation tend to operate in configurations of interconnected operating principles, routines and practices that commonly occur together (Meyer et al., 1993; Fiss, 2007). ${ }^{6}$ Roussel et al.'s (1991) offers a wellestablished typology of configurations for the organisational and managerial processes through which R\&D is developed (Lichtenhaler, 2003; Paraponaris, 2003; Park and Kim, 2005). It defines three configurations of $\mathrm{R} \& \mathrm{D}$ management (namely an intuitive, a systematic and a strategic R\&D mode) based on a number of salient characteristics related to management context and operating principles, routines and practices (e.g. funding, resource allocation, targeting, priority setting, measurement of results, evaluation of progress). Details of the key characteristics of each of these three R\&D modes can be found in Appendix 1. 
Typologies of R\&D management configurations can be extended and are useful in terms of identifying IMM configurations of innovation management (Nieto, 2002; Park and Kim, 2005). ${ }^{7}$ Drawing an analogy with Roussel et al.'s R\&D management modes, innovation management modes (IMM) are archetypes or commonly occurring configurations of organisational and managerial processes by which innovation arises and is managed. Hence, three IMM can be identified. In brief, an intuitive IMM conceives simple and isolated forms of innovation initiatives in a context of lack of a strategic framework for innovation management. In the systematic IMM, decisions regarding innovation initiatives are mostly taken on a projectby-project basis, while interrelationships among projects and the implications at the firm level are not addressed. Under the strategic IMM mode, firms emphasise the interrelationships among innovation initiatives and seek to create a strategically balanced portfolio of innovation initiatives formulated through the integration of technology and business perspectives (Roussel et al., 1991; Park and Kim, 2005). ${ }^{8}$

Given the purpose of this study, we have extended Roussel et al.'s framework to incorporate the implications of top managers' expertise into the definition of IMM. More specifically, external-oriented expertise (i.e. the expert knowledge, skills or experience of individual top managers in subjects related to product/market issues) (Hoffman and Hegarty, 1993) has been suggested as one of the relevant characteristics of individual top managers in explaining their influence on innovation (Thomas et al., 1991; Datta and Guthrie, 1994; Daellenbach et al., 1999; Barker and Mueller, 2002; Smith et al., 2005; Bergman et al., 2007; Hsu et al., 2008). External-oriented expertise influences manager's stock of knowledge and information processing capacity (Smith et al., 2005; Bergman et al., 2007). This stock and capacity make a particular difference in routines and patterns of practice in the strategic IMM, where complexity is higher because attention is focused on the creation of a balanced innovation portfolio throughout the firm. Consequently, we have considered it theoretically 
justified to break the strategic IMM into a strategic/non-expert IMM and a strategic/expert IMM. Under the former, external-oriented expertise makes it possible for senior managers to get effectively involved in the allocation of resources to specific projects (in contrast to the latter, where senior managers who lack an in-depth understanding of technology and markets are involved only in the overall assignation of resources to units). Furthermore, in strategic/expert IMM, senior managers are able to properly recognise, interpret and discriminate spontaneous bottom-up initiatives, which are welcome and encouraged (Goold and Campbell, 1987; Leonard-Barton, 1995; Kanter, 2001). In contrast, in strategic/non-expert IMM, innovation initiatives have to be channelled within previously established frameworks, with spontaneous personal initiatives outside this framework being considered disruptive and potentially subject to opportunistic behaviour (Hoffman and Hegarty, 1993).

In establishing its own operating principles, routines and practices, IMM differ from each other in three interrelated aspects. First, each IMM describes a different pattern of how heuristic processes are carried out and is associated to a specific cognitive model of innovation (Howells, 1995) by which reality concerning innovation issues is represented and made sense of, similarities between problems or opportunities are recognised and alternative solutions or initiatives are brought about and considered (Teece and Pisano, 1994; Nightingale, 1998; Markman and Gentner, 2001; Bergman et al., 2007). Second, different IMM emphasise different perceptions of the priority needs regarding information contents (Park and Kim, 2005). Finally, by proposing distinct linkages and information flows across organisational boundaries, each IMM frames the design and patterns of use of communication networks differently (Roussel et al., 1991).

\section{Theoretical development and formulation of hypotheses}




\section{Propositions Hla-Hld}

Both IMM and ICS frame how boundedly rational managers use heuristics to search for and process information and how they represent their organisations and environments in cognitive models for purposes of understanding, reasoning and decision-making (Howells, 1995; Markman and Gentner, 2001; Birnberg et al., 2007). Moreover, IMM influence the areas on which senior managers are interested in focusing organisational attention on, creating perceptions of relevance and priority needs regarding information contents, and shaping linkages and information flows across organisational boundaries (Roussel et al., 1991). ICS, in turn, are instrumental in focusing organisational attention in order to encourage innovative behaviours (Simons, 1995) and in acquiring, interpreting and diffusing information related to issues perceived as a priority by top managers (Chenhall, 2005). Thus, IMM and the interactive use of MACS appear to be highly interrelated.

An individual MACS should be more likely to be selected as the ICS under a given IMM if the heuristics and cognitive models framed by the MACS are compatible with and similar to the ones framed by the IMM (Birnberg et al., 2007; Bergman et al., 2007). Furthermore, the fact that each individual MACS presents idiosyncratic combinations of the information contents sophistication dimensions (Tillema, 2005) (e.g. scope, aggregation, integration) implies that each individual MACS is differently equipped to serve the diverse perceived priority information needs that arise in each IMM. Under a given IMM, an individual MACS should be more likely to be selected as the ICS if it is the best equipped to effectively provide the information perceived as a priority under that IMM. The choice should reinforce that ICS and IMM are mutually supportive and supplement each other. Overall, we expect that IMM will be relevant in conditioning the choice of which individual MACS are selected to introduce interactivity into the organisational control package. We next translate this generic 
line of argument into a set of testable hypotheses $\mathrm{H} 1 \mathrm{a}-\mathrm{H} 1 \mathrm{~d}$ which posit associations between specific IMM and the interactive use of individual MACS.

Under an intuitive IMM, there is no long-term innovation strategy framework and innovation activities are framed as overhead costs which are controlled at aggregate levels. Senior managers decide on the aggregate funding devoted to innovation but participate little in defining programmes or projects. In this IMM, top managers use heuristics and cognitive models that screen out information referring to the project level. They concentrate the information search and the representation of reality regarding innovation issues in a highly summarised overview of broad innovation features and in an outline of its effects on aggregate levels of expenditure and profitability. As far as the priority information needs are concerned, senior managers are likely to be interested in highly aggregated and highly integrated information rather than in data at lower-level units of analysis (e.g. lower level responsibility centres, specific projects) (Roussel et al., 1991) (see Table 1).

In this context, senior managers are likely to be interested in interactively using MACS that influence heuristics, represent reality and provide a structure for information storage and retrieval (Kadous and Sedor, 2004) in a way that provides elements for understanding, reasoning and predicting the implications of innovation at consolidated levels, disregarding details at lower levels. Budgets are unlikely to be used interactively under an intuitive IMM because the communication patterns of budget systems under this mode are characterised by a top-down cascade in which each level defines how it will spend his part, with little upward visibility and little attention from senior management on the disaggregated budget information (Roussel et al., 1991, p.29). In contrast, BSC, which are generally constructed top-down (Bourguignon et al., 2004), may be expected to provide holistic cognitive models which are particularly consistent with the heuristics and cognitive models framed by intuitive firms. Moreover, BSC present high levels of aggregation and portray integration by highlighting 
interdependencies between dimensions of the firm (Kaplan and Norton, 1996; Chong and Eggleton, 2003; Chenhall, 2005). Consequently, it is plausible that firms following an intuitive IMM are associated to an interactive use of BSC (see Note 5). This is formalised as:

\section{H1a: Firms following an intuitive innovation management mode are more likely to use interactively balanced scorecards than other individual management control systems.}

\section{INSERT TABLE 1 HERE}

In the systematic IMM, long- and short-term range plans and management instruments in general recognise projects as discrete and distinct activities of interest to senior managers. Decisions are mostly taken on a project-by-project basis and specific targets are set for each individual project, while the interrelationships among projects within and across businesses are omitted. Under a systematic IMM, heuristics and cognitive models are framed on a project-byproject basis. The information about innovation that senior managers perceive as deserving priority attention refers primarily to facets of the individual project level, and communication patterns are designed to ensure flows from each project to the top and back but not across projects (Roussel et al., 1991; Park and Kim, 2005). Since PMS represent the organisational reality through a cognitive model that provides a structure for information storage and retrieval (Kadous and Sedor, 2004) at the project level, the heuristics and cognitive models framed by PMS may be expected to be particularly consistent with the heuristics and cognitive models framed by firms under a systematic IMM. In terms of information contents, PMS are MACS that present medium scope (i.e. some selected financial and non-financial internal metrics), low levels of aggregation (i.e. information at the individual project level), and low levels of integration (i.e. little information on how the decisions made in one project influence other 
projects) (Van der Veeken and Wouters, 2002; PMI, 2004), which responds well to the information needs perceived as a priority under the systematic IMM (see Table 1). In summary, we posit that:

\section{H1b: Firms following a systematic innovation management mode are more likely to use interactively project management systems than other individual management control systems.}

Firms following a strategic/non-expert IMM seek to create a balanced portfolio of innovation initiatives. Within the constraints derived from the senior managers' lack of external-oriented expertise (Hoffmann and Hegarty, 1993; Smith et al., 2005), the strategic importance of individual projects and priorities are established on a firm-wide basis; and quite specific and precise goals are set and monitored for initiatives that fit into these priorities (Roussel et al., 1991). Under a strategic/non-expert IMM, firms tend to use corporate-wide heuristics and frame reality in holistic cognitive models that integrate local, lower-level projects (Howells, 1995). In terms of perceptions on priority needs regarding information contents, senior managers operating in a strategic/non-expert IMM are most likely to focus attention on information that does not require highly technical or external-oriented expertise in order to be interpreted. Moreover, communication networks are designed to facilitate flows across organisational boundaries.

In such context, senior managers are likely to select for interactive use an individual MACS that influences heuristics, represents reality and provides a structure for information storage and retrieval in a way that assists in understanding, reasoning and predicting interrelationships and trade-offs across the organisation. Furthermore, senior managers are likely to be interested in using interactively MACS that present a narrow scope, focusing primarily on internal financial data, and provide both disaggregated (at the project level) and aggregated (at the SBU or corporate level) information (see Table 1). Non-financial metrics 
provided by broader scope MACS may have little significance or be incomprehensible for senior managers with limited insight into technology and asset deployment, given their lack of external-oriented expertise (Hoffmann and Hegarty, 1993). In contrast, financial data may play an important role in scanning for managers who lack external-oriented expertise, since financial information is used to aggregate heterogeneous information about a set of diverse factors into a common dimension which is expressed in interpretable homogeneous terms (Galbraith, 1973; Van der Veeken and Wouters, 2002). Since budget systems force sharing of information and help achieve coordination across the organisation (Merchant and Van der Stede, 2006), are narrow in scope (centred in financial metrics) and provide both disaggregated and aggregated information (from lower-level responsibility centres or projects to the whole organisation) (Subramaniam and Mia, 2003), we expect that:

\section{H1c: Firms following a strategic/non-expert innovation management mode are more likely to use interactively budget systems than other individual management control systems.}

While both the strategic/non-expert and the strategic/expert IMM share corporate-wide heuristics and holistic portfolio-based cognitive models, the latter is further defined by the senior managers' high external-oriented expertise. Under a strategic/expert IMM, senior managers are conversant with technological, market and general business aspects and therefore do not exclude considering multi-faceted types of information as relevant (Howells, 1995; Humphreys and Cheng, 2008). Consequently, heuristics and cognitive models under a strategic/expert IMM may incorporate financial and non-financial dimensions, and the perceived priority needs regarding information contents may include both financial and nonfinancial items. Because of their corporate-wide, holistic approach, senior managers of firms under a strategic/expert IMM are likely to be more interested in interactively using MACS that present high levels of integration and aggregation. Since PMS are considered to provide low 
integration and low aggregation (Van der Veeken and Wouters, 2002; PMI, 2004), we do not expect PMS to be used interactively in firms following a strategic/expert IMM. In contrast, both budget systems and BSC provide a scope that should be interpretable by managers under a strategic/expert IMM, and both allow for high aggregation and present high integration. We therefore hypothesise that:

\section{H1d: Firms following a strategic/expert innovation management mode are more likely to use interactively balanced scorecards or budget systems than other individual management control systems.}

\section{Propositions $\mathrm{H} 2 \mathrm{a}-\mathrm{H} 2 \mathrm{~b}$}

Momentum is a pervasive tendency or force present in organisations by which organisations adhere to previous directions of evolution and persevere in pursuing courses of actions or in repeating patterns of change (Miller and Friesen, 1980; Kelly and Amburgey, 1991; Amburgey and Miner, 1992; Jansen, 2004). Strategic momentum applied to innovation (hereafter, innovation momentum) suggests that firms with a propensity to innovate will be inclined to become even more innovative, whereas those not inclined to innovate tend to further limit the circumstances under which they engage in innovation initiatives. In the absence of mitigating influences which attenuate these inclinations, innovation momentum can lead to dysfunctional excesses: In high-innovating firms, there is a risk of reaching too high a level of innovation in the sense that innovation is excessive, inadequate or produces dramatically diminished returns; in low-innovating firms, there is a risk of innovation sinking to a level which leads to complete strategic stagnation. The use of MACS can be instrumental in attenuating the tendency towards these dysfunctional excesses (Miller and Friesen, 1982).

Consistent with Miller and Friesen's seminal work, Bisbe and Otley (2004) found the influence of the interactive use of MACS on product innovation output to be dependant on the 
firm's level of innovation. On the one hand, they provide evidence consistent with the affirmation that, in high-innovating firms, the interactive use of MACS is associated to curbing innovation output levels. Building on the concept of control systems as mitigators of the dysfunctional excesses caused by strategic momentum, they argue that interactive controls help reduce the risk of excessive or inadequate innovation through increased initiative sharing and exposure, and through the provision of filters. On the other hand, and even though they found less conclusive evidence, Bisbe and Otley (2004) suggest that in low-innovating firms, innovation may be positively associated to an interactive use of MACS since interactive controls may contribute to overcoming organisational complacency by legitimating autonomous initiatives, introducing stimuli and providing guidance. We argue here that firms that choose to interactively use an individual MACS whose cognitive model and information contents are consistent with the cognitive model and the perceived priority information needs of the firm's IMM, will be better equipped to mitigate the dysfunctional excesses caused by innovation momentum. We next formalise this generic expectation in the form of two testable hypotheses. For that purpose, we consider that fit between IMM and ICS is present in a given situation if the association between specific IMM and ICS corresponds with one of the associations theoretically derived in Hla - Hld.

In the case of low-innovating companies, we expect that the ability of the ICS to break organisational complacency and to mitigate the tendency towards sinking innovation (Miller and Friesen, 1982) will be reinforced if a company chooses an ICS that provides heuristics and cognitive models (Birnberg et al., 2007) that are compatible with and supplement those provided by its IMM (Howells, 1995) and if, furthermore, the sophistication of the information contents (Chenhall and Morris, 1986; Tillema, 2005) provided by the ICS responds to the priority information needs perceived in the IMM (Roussel et al., 1991). If there is fit, lowinnovating firms should be better equipped to effectively introduce, when needed, 
legitimisation of bottom-up initiatives, stimulus and guidance (Bisbe and Otley, 2004), and the effects of the interactive MACS in enhancing innovation outputs should be enlarged. Thus:

H2a: As far as low-innovating firms are concerned, firms in which the individual MACS selected for interactive use fits with its innovation management mode will present higher levels of innovation outputs than firms in which the individual MACS selected for interactive use does not fit with its innovation management mode.

In high-innovating companies, we expect interactive MACS to help break the propensity towards excessive or inadequate innovation induced by strategic momentum (Miller and Friesen, 1982; Bisbe and Otley, 2004). If a high-innovating company chooses an interactive MACS that provides heuristics and cognitive models (Birnberg et al., 2007) that are compatible with and supplement the ones provided by its IMM (Roussel et al., 1991; Howell, 1995) and, furthermore, the information contents provided by the MACS (Chenhall and Morris, 1986; Tillema, 2005) responds to the priority information needs perceived in the IMM (Roussel et al., 1991), we expect it will be better equipped to effectively introduce, when needed, initiativesharing, exposure and provision of filters (Bisbe and Otley, 2004). As a result, if there is fit, the ability of the interactive MACS to help curb excessive or inadequate innovation should be accentuated and its effects in constraining innovation outputs should be reinforced. This is formalised as:

H2b: As far as high-innovating firms are concerned, firms in which the individual MACS selected for interactive use fits with its innovation management mode will present lower levels of innovation than firms in which the individual MACS selected for interactive use does not fit with its innovation management mode. 


\section{Research methodology and design}

\section{Sample selection and data collection}

Empirical data was gathered via a questionnaire sent by mail to a sample of CEOs of mediumsized, mature Spanish manufacturing firms. For the purposes of this research, medium-sized firms were defined as those with an annual turnover of between 18 and 180 million euros and between 200 and 2000 employees. In terms of life cycle, firms founded at least ten years before the survey was administered were considered to be mature. Manufacturing firms were defined as those within CNAE's (Clasificación Nacional de Actividades Económicas) Section D (Manufacturing Industries). For reasons of accessibility, we focused on firms headquartered in Catalonia (Spain). ${ }^{9}$ Exploitation of the Dun \& Bradstreet/CIDEM 2000 database yielded 120 firms meeting these screening criteria.

Instruments documented in academic literature as well as theoretical input from MACS and innovation research were used as the basis for an initial survey draft. The scale items included in the draft were circulated among six scholars with substantive or psychometric expertise and were pre-tested with three CEOs from medium-sized companies. Once revised on the basis of this feedback, questionnaires were distributed and returned by mail in keeping with the suggestions made by Dillman (2000). Out of the 120 distributed questionnaires, 57 were returned and complete. ${ }^{10}$ The process yielded a $47.5 \%$ response rate, which compares well with the response rate of similar studies (Van der Stede et al., 2007). Two-samples t-tests on means of all measured items for early and late respondents and the visual inspection of parallel boxplots supported the absence of any obvious non-response bias. Support in favour of the absence of common method variance caused by single-source bias was obtained using Harman's onefactor test (i.e. four factors with eigenvalues $>1$ ). 
Word count 13,761

Author's pre-publication proof

\section{Measurement of constructs}

\section{Interactive Use of MACS}

In this study, we pay special attention to three individual MACS, namely budget systems, BSC and PMS. Panel A in Table 2 reports the presence of the individual MACS in the sampled firms. Interactive use of the three individual MACS under study was measured by a multi-scale instrument developed by Bisbe and Otley (2004). This instrument captures properties of interactive MACS such as the pattern of attention of senior managers, the pattern of attention of middle management and the presence of face-to-face challenges and debate. Properties of interactive MACS such as focus on strategic uncertainties and inspirational involvement were omitted in this study (Bisbe et al., 2007). The questionnaire items are disclosed in Appendix 2. Factor analysis supported unidimensionality for each of the three selected MACS (Appendix 3). Three summated scales were created by adding the scores of the items related to each of the three MACS (in those cases where an individual MACS was not present, its interactive use received a zero score). The internal consistency of each of the three scales was assessed using Cronbach's $\alpha$. The three $\alpha$ were in the $0.77-0.78$ range, suggesting that the reliability of the constructs was acceptable. Panel B in Table 2 contains descriptives of these constructs.

\section{INSERT TABLE 2 HERE}

\section{Innovation Management Modes}

In order to empirically derive a taxonomy of IMM that was theoretically grounded in the typology proposed in Section 2, we selected the following attributes i) the degree of senior management involvement in the allocation of resources to specific projects (Roussel et al., 1991; Park and Kim, 2005) ii) the role of recognition of the bottom-up blossoming of autonomous innovation initiatives that emerge across the organisation (Goold and Campbell, 
1987; Roussel et al., 1991; Leonard-Barton, 1995; Kanter, 2001) iii) the extent to which portfolio techniques are used (Roussel et al., 1991; Miller and Morris, 1999) iv) the level of precision in project goal-setting and evaluation of progress (Roussel et al., 1991) v) the extent to which technical and business perspectives are integrated (Roussel et al., 1991; Miller and Morris, 1999) and vi) the existence of mechanisms for evaluating trade-offs among projects (Roussel et al., 1991).

Each of these six attributes was measured on a 7-point Likert scale that had two opposed statements as anchors (see Appendix 2 for questionnaire items). Scores on these items were then used to classify firms into groups, using a combination of hierarchical and nonhierarchical clustering algorithms. A hierarchical procedure (using Ward's method for distance measure) was first used to establish the number of clusters and to specify initial cluster seed points. In accordance with the indications of most typologies of $R \& D$ and innovation management modes, it was established that the number of interpretable clusters to be obtained from the data should be in the range of two to five. We examined all four alternatives (i.e. the two-, three-, four- and five-cluster solutions) derived from the combination of hierarchical and non-hierarchical procedures. After evaluating the results of all alternatives resulting from hierarchical procedures, we selected the four-cluster solution since it provided results that were interpretable given the theoretical configurations and given that the analysis of the alternative clustering solutions did not raise competing interpretable results. We subsequently used a nonhierarchical procedure (k-means SPSS' QUICKCLUSTER, which uses a parallel threshold method) to produce a cluster solution for a pre-specified number of four clusters. ${ }^{11}$ The resulting number of firms per cluster and the descriptive statistics of variables for each cluster are presented in Table 3.

INSERT TABLE 3 HERE 
We interpreted the results of the cluster analysis on the basis of the values of the clusters' centroids, leading to the profiles summarised in Table 4. The resulting profiles could be meaningfully related to the theoretical framework and configurations proposed by the typology of IMM described in Section 2, and labels were assigned correspondingly.

\section{INSERT TABLE 4 HERE}

\section{Innovation}

While innovative activity takes many different forms (Damanpour, 1991; Johanessen et al., 2001; García-Valderrama et al., 2003; OECD, 2005), in this paper we focus specifically on product innovation. Product innovation is understood here from an output perspective, and it is defined as the development and launch of products which are in some objective respect unique or distinctive from existing products (Higgins, 1996; OECD, 2005). The firm level is taken as the minimum level of institutional novelty to define the scope of product innovation (Kamm, 1987; Souder, 1987; Bart, 1991; Li and Atahuene-Gima, 2001; OECD, 2005).

In order to measure product innovation, we relied on the scale used by Bisbe and Otley (2004), which drew on instruments proposed by Capon et al. (1992), Scott and Tiessen (1999) and Gemser and Leeenders (2001), and adapted them to reflect innovation from an output perspective. The instrument consists of three items measured through 7-point Likert scales, namely the rate of introduction of new products, the tendency of firms to pioneer, and the part of the product portfolio corresponding to recently launched products. Anchors for the three Likert scales refer to innovative / non-innovative behaviours during the last three years in relative terms, in comparison with the industry average (see Appendix 2 for questionnaire 
items). Factor analysis supported unidimensionality with a $75.44 \%$ of variance explained (Appendix 3). A summated scale was created by adding the scores of the three items and reversed so that high scores represented high levels of innovation (see Panel B in Table 2 for descriptives). A Cronbach- $\alpha$ of 0.83 indicated high internal consistency of the summated scale.

\section{Results}

Table 5 provides descriptive statistics regarding the interactive use of the three different individual MACS captured in this study and of innovation within each of the four IMM.

\section{INSERT TABLE 5 HERE}

In order to test $H I a$ through $H I d$, we examined whether differences among pairs of MACS within each IMM were significant. We restricted our analysis to the pairs of MACS which corresponded to the expected differences as derived from the formulation of $\mathrm{Hla}$ through H1d. Table 6 reports the results of the battery of Wilcoxon matched-pairs signed-ranks tests which were used to examine these pair-wise comparisons. ${ }^{12}$

\section{INSERT TABLE 6 HERE}

As indicated in Table 6, significant differences arose in the comparison between pairs of MACS in 3 out of 4 IMM. Excluding the systematic IMM (for which no significant differences were detected), significant differences were observed in 5 out of 6 compared pairs, all of which were in the direction posited by the hypotheses. At the level of the specific IMM, pair-wise comparisons among MACS within the intuitive IMM suggested that, as predicted by Hla, 
firms under this mode are more likely to use interactively BSC than both budget and project management systems (PMS) $(\mathrm{p}<0.05)$. In contrast, no significant differences between pairs of interactive use of individual MACS were found in the systematic subgroup (even though results indicated that the interactive use of PMS is marginally higher in firms under a systematic mode than in other firms). In the strategic/non-expert subgroup, as expected, firms appeared to be more likely to use interactively budget systems than other individual MACS. However, while the difference with PMS is significant $(\mathrm{p}<0.05)$, the difference between budget systems and BSC is not. Regarding the strategic/expert IMM, significant differences arose between the interactive use of PMS and the interactive use of both budgets $(\mathrm{p}<0.01)$ and BSC $(\mathrm{p}<0.05)$, supporting the postulate that firms under this IMM are more likely to use interactively BSC or budgets than PMS. Overall, our empirical results indicated that Hla and Hld are supported, that $H 1 c$ is partially supported, and that no supporting evidence was found in favour of $H 1 b$.

In order to test $H 2$ and $H 2 b$, we classified firms in two subgroups, based on whether the MACS chosen for interactive use coincided with the individual MACS posited by hypotheses $H I a$ to $H I d$. Firms were classified as 'fit' if the MACS with the highest interactive use score coincided with the theoretically derived fit proposed in the hypotheses. Thus, intuitive firms where USEBSC > USEBUD and USEPMS; systematic firms where USEPMS > USEBUD and USEBSC; strategic/non-expert firms where USEBUD > USEPMS and USEBSC; and strategic/expert where USEBUD or USEBSC > USEPMS were classified as cases of 'fit' ( $\mathrm{n}=$ 30). Otherwise, firms were classified as cases of 'non-fit' $(n=27)$. We subsequently performed two Mann-Whitney U tests; one comparing innovation scores between 'fit' firms and 'non-fit' firms in low-innovating firms (innovation score $\leq$ median 14.00) $(H 2 a)$, and a second replicating this analysis for high-innovating firms (innovation scores $>$ median) $(H 2 b)$. As shown in Table 7 Panel A, results suggest that for both the low- and high- innovation subsamples, there is a significant difference $(\mathrm{p}<0.05)$ in the level of innovation between firms in 
which the individual MACS selected for interactive use corresponds with the conceptuallyderived fit and firms in which there is no such fit. Univariate results suggest that, for lowinnovating firms, innovation scores are significantly higher in non-fit firms whereas, for highinnovating firms, they are significantly higher in 'fit' firms. Multivariate results for both lowand high-innovating firms controlling for IMM, ICS and size (see Table 7 Panel B) were consistent with the Mann-Whitney U results. For low-innovating firms, the coefficient of the variable FIT was negative and significant at $\mathrm{p}<0.05$ level. For high-innovating firms, the coefficient of the variable FIT was positive and significant $(\mathrm{p}<0.01)$. In summary, while the evidence reported in both panels of Table 7 supports the existence of significant differences in the level of innovation between 'fit' and 'non-fit' firms, the detected differences appeared to be in the opposite direction of the predicted signs that were posited in $\mathrm{H} 2 \mathrm{a}$ and $\mathrm{H} 2 \mathrm{~b}$.

\section{INSERT TABLE 7 HERE}

\section{Conclusion}

The aim of this study is to contribute to the emerging Levers of Control (LOC) literature on the relationships between innovation and management accounting and control systems (MACS) by providing insights on the choice made by senior managers in selecting which individual MACS are selected for interactive use (interactive control systems, ICS), as well as on the impact of this choice on innovation outcomes. In particular, this paper addresses two research questions 1) whether the choice of individual MACS selected for interactive use (Simons, 1995, 2000) is associated to the internal configurations of organisational and managerial processes by which innovation arises (i.e. Innovation Management Modes, IMM) (Roussel et al., 1991; Park and Kim, 2005) and 2) whether the expected patterns of fit between specific IMM and the 
individual MACS selected for interactive use are translated into beneficial implications on innovation outputs.

Regarding the first research question, we have argued that the choice of interactive MACS is deliberate and systematic and is likely to be associated to the type of IMM followed by the firm. We base this expectation on arguments claiming that this choice pursues 1) the compatibility and similarity between the heuristics and cognitive models provided by the firm's IMM on the one hand, and by the MACS used interactively on the other hand (Howells, 1995; Birnberg et al., 2007) and 2) the ability of the idiosyncratic information provision characteristics of individual MACS to effectively respond to the diverse perceived information needs that arise in each IMM (Chenhall and Morris, 1986; Roussel et al., 1991; Tillema, 2005). We have consequently argued that firms following a given IMM should be more likely to use interactively an individual MACS (in comparison with other MACS) which is compatible with and presents similar characteristics to the IMM followed by the firm, with both IMM and individual MACS supplementing each other and being mutually supportive. We have established these expected associations as situations of fit.

This generic statement has been further developed through four hypotheses that posited specific expected directions of fit between IMM and interactive MACS (i.e. we expected firms under an intuitive IMM to select BSC for interactive use; project management systems in the systematic IMM; budget systems in the strategic/non-expert IMM; and budgets or BSC in the strategic-expert IMM). The empirical evidence from medium-sized firms provided in this study is at least partially consistent with these expected associations. Hence, we found results supporting two of our hypotheses (the ones related to intuitive and strategic/expert IMM), partial support for the hypothesis related to the strategic/non-expert IMM, whereas results related to the systematic IMM were not significant. Overall, the gathered evidence provides at least partial support for the theoretical development establishing that firms pursue 
compatibility, similarity and mutual support between IMM and ICS and that the choice regarding the specific MACS to be used interactively in a firm is associated to the type of IMM followed by the firm.

Our second research question referred to the extent to which fit between IMM and ICS result in beneficial outcomes. Based on Bisbe and Otley (2004), we considered that the beneficial outcome that should be expected from the theoretically-derived fit between IMM and ICS is an enhanced ability to mitigate the potential dysfunctional excesses caused by innovation momentum (Miller and Friesen, 1982). The results of our study indicate that there is in fact a significant difference in the level of innovation between those firms in which the individual MACS selected for interactive use corresponds with the conceptually-derived fit and those firms in which there is no such correspondence. However, we found this effect to occur in the opposite direction to what we had originally predicted.

More precisely, we expected that in the case of low-innovating firms, firms which present fit between IMM and ICS would be better equipped to break organisational complacency and, consequently, fit would eventually result in higher levels of innovation than those obtained in absence of fit. Contrary to our expectation, we found low-innovating firms in which the MACS selected for interactive use under a given IMM corresponded to the conceptually-derived fit to present even lower levels of innovation. Analogously, in the case of high-innovating firms, fit between IMM and ICS was expected to better equip firms to break the tendency towards excessive or inadequate innovation and, consequently, fit was expected to result in lower levels of innovation than those obtained in absence of fit. However, we found evidence suggesting that when the MACS selected for interactive use under a given IMM corresponded to the conceptually-derived fit, firms were likely to present higher levels of innovation than firms which did not present such fit. Altogether, our results regarding $H 2 a$ and $H 2 b$ indicate that firms in which the individual MACS selected for interactive use fits with its IMM (i.e. IMM 
and MACS present similar heuristics and cognitive models, and ICS obediently provide the information needs that are perceived as a priority by senior management given the emphasis of its IMM) are less effective in mitigating the dysfunctional excesses of innovation momentum than firms in which there is no such fit.

A plausible avenue to interpret this finding is that the ability to effectively mitigate the dysfunctional excesses of innovation momentum is more likely to result from the introduction of elements which, rather than replicate and fully conform to existing patterns, introduce diversity, offer new perspectives and even produce some disruption. This argument can be related to the distinction proposed in the psychology literature between supplementary fit and complementary fit (Cable and Edwards, 2004). Importing an analogy from this literature into our discussion, supplementary fit would refer to situations in which entities (i.e. IMM and MACS) possess similar or matching characteristics, and the characteristics of one component replicate to a large extent the characteristics of other components. In contrast, complementary fit refers to situations in which the weaknesses or actual needs of one entity are offset by the strengths of other entities. In our theoretical development, we implicitly framed our hypotheses in terms of supplementary fit. The evidence we have found at least partially supports the set of hypotheses that postulate that IMM are associated to the interactive use of those individual MACS which provide supplementary fit. However, our findings indicate that this supplementary fit does not in fact lead to an enhanced ability to mitigate the dysfunctional excesses of innovation momentum, but rather may lead to its reinforcement. Our results allow us to speculate that this ability is more likely to arise from the richness derived from the introduction of elements that do not fully conform to existing patterms and offer instead new, complementary perspectives (i.e. complementary fit). We leave for future research the development of theory and empirical evidence concerning the implications of the distinction between supplementary and complementary fit. 
Several limitations of the current study may be noted. By concentrating on ICS, this study does not permit analysis of the interplay between diagnostic MACS, interactive MACS and the other MACS within the control package (Otley, 1980; Merchant and Otley, 2007; Widener, 2007; Malmi and Brown, 2008) Moreover, its cross-sectional nature does not allow for a process-based understanding of the dynamics of the choice of the ICS. Our findings provide useful insights that could form the basis for future qualitative research examining the dynamics of the process by which an individual MACS is chosen for interactive use under different IMM, as well as the dynamics of the implications of this choice regarding innovation momentum. Finally, given the limitations in sample size, and the specificities regarding firm size, industries and location, generalisation of the results should be done with caution.

Despite these limitations, this paper contributes to the development of LOC theory by emphasising the relevance of the choice of individual MACS to be used interactively. This issue, crucial in LOC theory, had been under-researched in prior empirical literature. The results presented in this study contribute in this regard on several grounds. First, we have covered several individual MACS that are candidates for interactive use, which has allowed us to highlight the idiosyncrasies of each individual MACS should it be selected for interactive use. Second, we have developed LOC theory's claim that the choice of ICS is not random but systematic by providing evidence which supports that the choice of ICS is associated to the configurations of organisational and managerial processes through which innovation arises (IMM). Moreover, we have introduced a new angle into the discussion about the effects of ICS on innovation by concluding that innovation output levels are affected by the presence or absence of fit between the IMM followed by a firm and the individual MACS selected for interactive use. Finally, the results of our study suggest that supplementary fit between IMS and ICS may not be instrumental in mitigating the dysfunctional excesses of innovation momentum, but instead may reinforce the tendency towards them. Overall, we expect our 
findings to contribute to the awareness of the importance of the choice of the individual MACS selected for interactive use within the LOC framework. Future LOC studies should strive to integrate issues surrounding ICS choice with research into the interplay between levers. We belief that this integration will enhance the ability of researchers to capture how firms successfully manage the tension between the need for the predictable achievement of preestablished objectives and the need for creative innovation and how the management of this tension is ultimately reflected in long-term performance. 
Word count 13,761

Author's pre-publication proof
To appear in European Accounting Review DOI no: 1031080/09638180902863803

\section{Appendix 1. Roussel et al's framework of R\&D Management Modes}

\begin{tabular}{|c|c|c|c|}
\hline & Intuitive mode & Systematic mode & Strategic mode \\
\hline Context & $\begin{array}{l}\text { - } \quad \text { No long-term strategic } \\
\text { framework } \\
\text { - } \quad \text { R\&D is an overhead cost }\end{array}$ & $\begin{array}{ll}-\quad \text { Transition state } \\
\text { - } \quad \text { Partial strategic framework }\end{array}$ & - $\quad$ Holistic strategic framework \\
\hline Philosophy & $\begin{array}{l}\text { - } \quad \text { R\&D decides future } \\
\text { technologies } \\
\text { Business decides current } \\
\text { technology objectives }\end{array}$ & $\begin{array}{l}\text { - Judge-advocate } \\
\text { management/R\&D relationship } \\
\text { - Customer-supplier } \\
\text { business/R\&D relationship }\end{array}$ & - $\quad$ Partnership \\
\hline Organisation & 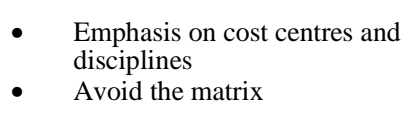 & $\begin{array}{l}\text { - } \quad \text { Centralised and decentralised } \\
\text { Matrix management of projects }\end{array}$ & - $\quad$ Breaks the isolation of $\mathrm{R} \& \mathrm{D}$ \\
\hline $\begin{array}{l}\text { Technology/ } \\
R \& D \text { strategy }\end{array}$ & $\begin{array}{l}\text { - No explicit link to business } \\
\text { strategy } \\
\text { Technology first, business } \\
\text { implications later }\end{array}$ & $\begin{array}{l}\text { - Strategic framework by project } \\
\text { No integration business- or } \\
\text { corporatewide }\end{array}$ & $\begin{array}{l}\text { - Technology/R\&D and } \\
\text { business strategies integrated } \\
\text { corporatewide }\end{array}$ \\
\hline $\begin{array}{l}\text { Operating principles, } \\
\text { routines and practices }\end{array}$ & 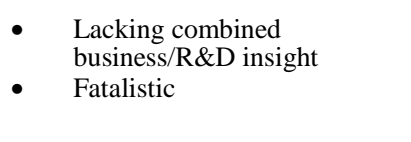 & 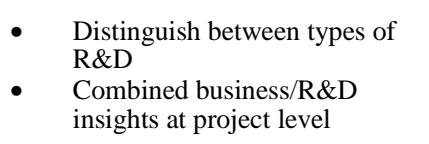 & $\begin{array}{l}\text { - Combined R\&D/business } \\
\text { insights across the spectrum }\end{array}$ \\
\hline Funding & $\begin{array}{l}\text { - Line item in annual budget } \\
\text { - } \quad \text { Fund what you can afford }\end{array}$ & 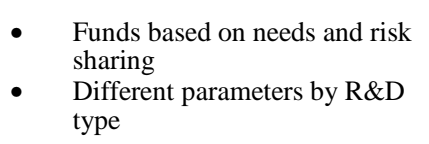 & $\begin{array}{l}\text { - Varies with technology } \\
\text { maturity and competitive } \\
\text { impact }\end{array}$ \\
\hline Resource allocation & $\begin{array}{l}\text { - } \quad \text { At the discretion of R\&D } \\
\text { - No upward visibility }\end{array}$ & $\begin{array}{l}\text { - To fundamental R\&D by } \\
\text { central R\&D management } \\
\text { To other R\&D jointly by } \\
\text { customers and suppliers } \\
\text { separately in each area }\end{array}$ & $\begin{array}{l}\text { - Based on balancing of } \\
\text { priorities and risk/reward } \\
\text { trade-offs across areas }\end{array}$ \\
\hline Targeting & $\begin{array}{l}\text { - Is anathema for fundamental } \\
\text { and radical R\&D } \\
\text { Business and technological } \\
\text { objectives sequential }\end{array}$ & $\begin{array}{l}\text { - } \quad \begin{array}{l}\text { Consistent business and } R \& D \\
\text { objectives by project for }\end{array} \\
\text { incremental and radical R\&D } \\
\text { - Targets precisely defined }\end{array}$ & $\begin{array}{l}\text { - All R\&D has defined } \\
\text { consistent business and } \\
\text { technological objectives } \\
\text { located within a firm-wide } \\
\text { portfolio } \\
\text { Targets precisely defined }\end{array}$ \\
\hline Priority setting & $\begin{array}{l}\text { - } \quad \text { No strategic priorities } \\
\text { Priorities vary with } \\
\text { operational circumstances }\end{array}$ & $\begin{array}{l}\text { - } \quad \text { For fundamental R\&D by } \\
\text { central R\&D management } \\
\text { - } \quad \text { For other R\&D jointly by } \\
\text { customers and suppliers } \\
\text { separately in each area }\end{array}$ & $\begin{array}{l}\text { - Across areas, according to } \\
\text { cost/benefits and contribution } \\
\text { to strategic objectives }\end{array}$ \\
\hline Measuring results & $\begin{array}{l}\text { Expected results not } \\
\text { precisely defined } \\
\text { Measurements often } \\
\text { misleading }\end{array}$ & $\begin{array}{l}\text { - } \quad \begin{array}{l}\text { Expected results precisely } \\
\text { defined at the project level }\end{array} \\
\text { - } \quad \text { Quantitative for incremental } \\
\text { R\&D } \\
\text { - "Market intelligence gap" for } \\
\text { radical R\&D }\end{array}$ & $\begin{array}{ll}\text { - } & \begin{array}{l}\text { Expected results precisely } \\
\text { defined }\end{array} \\
\text { - } & \text { Portfolio perspective } \\
\text { - } & \text { Against business objectives } \\
\text { and technological } \\
\text { expectations }\end{array}$ \\
\hline Evaluating progress & $\begin{array}{ll}\text { - } & \text { Ritualistic and perfunctory } \\
\text { - } & \text { Periodic }\end{array}$ & $\begin{array}{l}\text { - } \quad \text { Formalised peer reviews } \\
\text { Good communications with } \\
\text { businesses for incremental and } \\
\text { radical R\&D projects }\end{array}$ & $\begin{array}{l}\text { Regularly and when external } \\
\text { events and internal } \\
\text { developments warrant }\end{array}$ \\
\hline
\end{tabular}


Word count 13,761

Author's pre-publication proof
To appear in European Accounting Review DOI no: 1031080/09638180902863803

Source : adapted from Roussel et al., (1991) 


\section{Appendix 2. Questionnaire Items}

\section{Innovation}

(In comparison with the industry average).

- (1) During the last three years we have launched many new products (new to the firm) vs. (7) few new products.

- (1) In new products, we are very often first-to-market vs. (7) very rarely first-to-market.

- (1) The percentage of new products in our product portfolio is much higher than industry average vs. (7) is much lower than industry average.

\section{Innovation Management Modes}

- (1) I am involved in the overall allocation of resources to innovation, but not in the decisions about the specific project lines to which these resources will be allocated vs. (7) I am involved in the choice of innovation lines as well as in the decisions about specific projects to which these resources will be allocated (Allocation).

- (1) Innovation always takes place within a previously established framework. Spontaneous personal initiatives disrupt this framework. vs. (7) Innovation often arises from spontaneous personal initiatives. For me, it is essential to identify and support such initiatives (Recognition).

- (1) When approving, measuring results of or evaluating an innovation project, decisions are based above all on the specific features of that individual project vs. (7) decisions are based above all on that project's place in our project portfolio.(Portfolio).

- (1)For every project, we always quantify precise objectives (e.g. time, cost, quality) and measure our progress in relation to those objectives vs. (7) It is common that for some projects we do not quantify precise objectives and consequently we do not follow-up progress towards these objectives (Precision).

- (1) Managers of innovative units should competently manage their area. It is not their role to have an overall vision of the business, nor contribute to deciding the general innovation policy vs. (7) Apart from competently managing their area, managers of innovative units should have an overall vision of the business and contribute to shaping the general innovation policy (Tech/Buss).

- (1) When we are planning, the decision about which particular project should go ahead is taken within each area. vs. (7) is taken globally. We compare innovation projects from different areas and prioritise among them.(Trade-offs).

\section{Interactive Use of MACS}

Is some kind of budgetary system (definition included in original questionnaire) used in your company? (Yes/no). If yes, then (ib. id. for balanced scorecard-tableaux de bord or other multidimensional performance measurement systems and for project management systems)

- (1) Only when there are deviations from planned performance are budget follow-up reports the main subject for face-to-face discussion with my executive team vs. (7) Whether there are deviations from planned performance or not, budget follow-up reports are the main subject for face-to-face discussion with my executive team.

- (1) I pay periodic or occasional attention to budgets (e.g. setting objectives, analyzing periodic followup reports,...) vs. (7) I pay regular and frequent attention to budgets. I use them permanently.

- (1) For many managers in my company, budgets require periodic or occasional, but not permanent, attention vs. (7) In my company, budgets require permanent attention from all managers. 


\section{Appendix 3. Factor Analysis* and Reliability Analysis}

\begin{tabular}{|c|c|c|c|c|}
\hline & Variable & Items in questionnaire & & Factor 1 \\
\hline \multirow{3}{*}{ MACS } & $\begin{array}{c}\text { Interactive Use of } \\
\text { Budgets } \\
\text { (USEBUD) }\end{array}$ & $\begin{array}{l}\text { face-to-face challenge on a continuous basis } \\
\text { permanent personal attention by the CEO } \\
\text { permanent personal attention by managers }\end{array}$ & $\begin{array}{l}\text { Eigenvalue } \\
\% \text { of variance } \\
\text { Cronbach's } \alpha\end{array}$ & \begin{tabular}{|c|}
$\mathbf{0 . 8 5 4}$ \\
$\mathbf{0 . 8 7 1}$ \\
$\mathbf{0 . 7 5 5}$ \\
2.06 \\
$68.60 \%$ \\
0.77 \\
\end{tabular} \\
\hline & $\begin{array}{c}\text { Interactive Use of } \\
\text { Balanced Scorecards } \\
\text { (USEBSC) }\end{array}$ & $\begin{array}{l}\text { face-to-face challenge on a continuous basis } \\
\text { permanent personal attention by the CEO } \\
\text { permanent personal attention by managers }\end{array}$ & $\begin{array}{l}\text { Eigenvalue } \\
\% \text { of variance } \\
\text { Cronbach's } \alpha\end{array}$ & $\begin{array}{c}\mathbf{0 . 8 3 2} \\
\mathbf{0 . 8 5 4} \\
\mathbf{0 . 8 1 9} \\
2.09 \\
69.75 \% \\
0.78 \\
\end{array}$ \\
\hline & $\begin{array}{l}\text { Interactive Use of } \\
\text { Project Mgmt.Syst. } \\
\text { (USEPMS) }\end{array}$ & $\begin{array}{l}\text { face-to-face challenge on a continuous basis } \\
\text { permanent personal attention by the CEO } \\
\text { permanent personal attention by managers }\end{array}$ & $\begin{array}{l}\text { Eigenvalue } \\
\% \text { of variance } \\
\text { Cronbach's } \alpha\end{array}$ & $\begin{array}{c}\mathbf{0 . 7 7 0} \\
\mathbf{0 . 8 7 9} \\
\mathbf{0 . 8 7 9} \\
2.13 \\
71.24 \% \\
0.78 \\
\end{array}$ \\
\hline & $\begin{array}{l}\text { Innovation } \\
\text { (INNOV) }\end{array}$ & $\begin{array}{l}\text { rate of introduction of new products } \\
\text { tendency of firms to pioneer/being first-to-market } \\
\% \text { sales from recently launched products }\end{array}$ & $\begin{array}{l}\text { Eigenvalue } \\
\% \text { of variance } \\
\text { Cronbach's } \alpha\end{array}$ & \begin{tabular}{|c|}
$\mathbf{0 . 8 5 6}$ \\
$\mathbf{0 . 8 5 9}$ \\
$\mathbf{0 . 8 9 1}$ \\
2.26 \\
$75.44 \%$ \\
0.83 \\
\end{tabular} \\
\hline
\end{tabular}

* Factor loadings based on principal component analysis. Rotated solutions using VARIMAX.

For individual MACS, unidimensionality and reliability of the constructs related to interactive use were assessed taking into account the observations from the full sample that reported to use that individual MACS ( $n=55$ for budgets; $n=45$ for BSC; $n=36$ for project management systems). The rationale for ignoring non-users was to avoid a potential bias towards unidimensionality and high reliability just because all items for non-users were systematically scored as zero. Inclusion of all cases also supported the dimensionality structure and reliability analysis presented here. 
Word count 13,761

Author's pre-publication proof
To appear in European Accounting Review DOI no: 1031080/09638180902863803

\section{References}

Abernethy, M. A. and Brownell, P. (1999) The role of budgets in organizations facing strategic change: an exploratory study, Accounting, Organizations and Society, 24(3), pp. 189-204.

Ahrens, T. and Chapman, C. S. (2004) Accounting for flexibility and efficiency: A field study of management control systems in a restaurant chain, Contemporary Accounting Research, 21(2), pp. 271-301.

Amburgey, T.L. and Miner, A.S. (1992) Strategic momentum: the effects of repetitive, positional and contextual momentum on merger activity, Strategic Management Journal, 13, pp. 335-348.

Barker, V. L. and Mueller, G.C. (2002) CEO characteristics and firm R\&D spending, Management Science, 48(6), pp. 782801.

Bart, C. (1991) Controlling new products in large diversified firms: a presidential perspective, Journal of Product Innovation Management, 8(1), pp. 4-17.

Bergman, J.K., Jantunen, A., Saksa, J-M and Hurmelinna-Laukkanen, P. (2007) International Journal of Learning and Change, 2(1), pp. 34-50.

Birnberg, J., Luft, J. and Shields, M. (2007) Psychology Theory in Management Accounting Research, in C.S. Chapman, A.G. Hopwood, and M. D. Shields (Eds) Handbook of management accounting research, pp. 113-136 (Oxford: Elsevier).

Bisbe, J. and Otley, D. (2004) The effects of the interactive use of management control systems on product innovation, Accounting, Organizations and Society, 29(8), pp. 709-737.

Bisbe, J., Batista-Foguet, J. and Chenhall, R. (2007) Defining management accounting constructs: A methodological note on the risks of conceptual misspecification, Accounting, Organizations and Society, 32(7-8), pp. 789-820.

Bonner, J. M., Ruekert, R. W. and Walker, O. C. (2002) Upper management control of new product development projects and project performance, Journal of Product Innovation Management, 19(3), pp. 233-245.

Bonner, J.M. (2005) The influence of formal controls on customer interactivity in new product development, Industrial Marketing Management, 34(1), pp. 63-69.

Bourguignon, A., Malleret, V. and Nørreklit, H. (2004) The American balanced scorecard versus the French tableau de bord: the ideological dimension, Management Accounting Research, 15(2), pp. 107-134.

Bouwens, J. and Abernethy, M.A. (2000) The consequences of customization on management accounting system design, Accounting, Organizations and Society, 25(3), pp. 221-241.

Buesa, M and Molero, J (1998) Economía industrial de España: organización, tecnología e internacionalización. (Madrid:

Civitas).

Cable, D. M. and Edwards J. R. (2004) Complementary and supplementary fit: a theoretical and empirical integration, Journal of Applied Psychology, 89(5), pp. 822-834.

Capon, N., Farley, J. U., Lehmann, D. R., and Hulbert, J. M. (1992) Profiles of product innovators among large US manufacturers, Management Science, 38(2), pp. 157-169.

Cardinal, L. (2001) Technological innovation in the pharmaceutical industry: The use of organisational control in managing research and development, Organization Science, 15(4), pp. 411-431.

Chapman, C.S. (1998) Accountants in organisational networks, Accounting, Organizations and Society, 23(8), pp. 737-766.

Chenhall, R.H. (2005) Integrative strategic performance measurement systems, strategic alignment of manufacturing, learning and strategic outcomes: an exploratory study, Accounting, Organizations and Society, 30(5), pp. 395-422.

Chenhall, R.H. (2007) Theorizing contingencies in management control systems research, in C.S. Chapman, A.G. Hopwood, and M. D. Shields (Eds) Handbook of management accounting research, pp.163-195 (Oxford: Elsevier).

Chenhall, R.H., Hall, M. and Smith, D. (2008) Social capital and management control systems: a study of a non-government organization, $6^{\text {th }}$ Conference on New Directions in Management Accounting, EIASM Brussels, Belgium, 15-17 
Word count 13,761

Author's pre-publication proof
To appear in European Accounting Review DOI no: 1031080/09638180902863803

December, 2008.

Chenhall, R.H. and Langfield-Smith, K. (1998) The relationship between strategic priorities, management techniques and management accounting: an empirical investigation using a systems approach, Accounting, Organizations and Society, 23(3), pp. 243-264.

Chenhall, R. H. and Morris, D. (1986) The impact of structure, environment and interdependence on the perceived usefulness of management accounting systems, The Accounting Review, 61(1), pp. 16-35.

Chiapello, E. (1996) Les typologies des modes de contrôle et leurs facteurs de contingence: un essai d'organization de la littéerature, Comptabilité-Contrôle-Audit, 2, pp. 51-74.

Chong, V. K. and Eggelton, I. R. (2003) The decision-facilitating role of management accounting systems on managerial performance: the influence of locus of control and task uncertainty, Advances in Accounting, 20, pp. 165-197.

Covaleski M. A., Evans, J. H. III, Luft, J. L. and Shields, M. D. (2003) Budgeting Research: Three Theoretical Perspectives and Criteria for Selective Integration, Journal of Management Accounting Research, 15(1), pp. 3 - 49.

Daellenbach, U. S. McCarthy, A. M. and Schoenecker, T. S. (1999) Commitment to innovation: the impact of top management team characteristics, $R \& D$ Management, 29(3), pp. 199-208

Damanpour, F. (1991) Organisational innovation: A meta analysis of effects of determinants and moderators, Academy of Management Journal, 34(3), pp. 555-590.

Datta, D. K. and Guthrie, J. P. (1994) Executive succession: Organizational antecedents of CEO characteristics, Strategic Management Journal, 15(7), pp. 569-577.

Davila, T. (2000) An empirical study on the drivers of management control systems design in new product development, Accounting, Organizations and Society, 25(4-5), pp. 383-410.

Davila, T. (2005) The Promise of Management Control Systems for Innovation and Strategic Change, in C.S. Chapman (Ed.) Controlling Strategy: management, accounting and performance measurement, pp. 37-61 (Oxford: Oxford University Press).

Davila, T., Epstein, M. J. and Matusik, S. F. (2005) Innovation strategy and the use of performance measures, Advances in Management Accounting, 13, pp. 27-58.

Davila, A., Foster, G. and Li, M. (2008) Reasons for management control systems adoption: Insights from product development systems choice by early-stage entrepreneurial companies, Accounting, Organizations and Society, doi: 10.1016/j.aos.2008.08.002 (forthcoming)

Dillman, D.A. (2000) Mail and Internet Surveys. (New York: John Wiley and Sons, Inc).

Ditillo, A. (2004) Dealing with uncertainty in knowledge-intensive firms: the role of management control systems as knowledge integration mechanisms, Accounting, Organizations and Society, 29(3-4), pp. 401-421.

Dun \& Bradstreet / CIDEM (2000) Cens Estadístic Catalunya 20000 Principals Empreses Catalanes (Barcelona: Dun \& Bradstreet).

Epstein, M. and Manzoni, J.F. (1997) The balanced scorecard and tableau de bord: translating strategy into action, Management Accounting, 79(2), pp. 28-36.

Escorsa, P. and Valls, J. (2003) Tecnologia i innovació: Direcció i gestió. (Barcelona: Edicions UPC).

Fiss, P. C. (2007) A set-theoretic approach to organisational configurations, Academy of Management Review, 32(4), pp. 1180-1198.

Galbraith, J. (1973) Designing complex organizations. (Reading: Addison-Wesley Publishing Company).

García-Valderrama, T., Rodríguez, G. C. and Pinzón, P. A. (2003) Hacia la medida de la innovación empresarial: el proceso de validación de escalas, Revista española de financiación y contabilidad, 116, 2003, pp. 17-62.

Garengo, P., Biazzo, S. and Bititci, U. S. (2005) Performance Measurement Systems in SMEs: A Review for a Research Agenda, International Journal of Management Reviews, 7(1), pp. 25-47.

Gehrke, I. and Horvath, P. (2002) Implementation of performance measurement: a comparative study of French and German organizations, in M.J. Epstein and J.F. Manzoni (Eds) Performance Measurement and Management Control: A 
Word count 13,761

Author's pre-publication proof
To appear in European Accounting Review DOI no: 1031080/09638180902863803

Compendium of Research, Studies in Financial and Management Accounting, 9, pp. 159-180 (London: JAI Press).

Gemser, G. and Leenders, M.A. (2001) How integrating industrial design in the product development process impacts on company performance, Journal of Product Innovation Management, 18(1), pp. 28-38.

Gerdin, J. and Greve, J. (2004) Forms of contingency fit in management accounting research: A critical review, Accounting, Organizations and Society, 29(3-4), pp. 303-326.

Gerdin, J. and Greve, J. (2008) The appropriateness of statistical methods for testing contingency hypotheses in management accounting research, Accounting, Organizations and Society, 33 (7-8), pp. 995-1009.

Goold, M. and Campbell, A. (1987) Strategies and styles: the role of the centre in managing diversified corporations (Oxford: Basil Blackwell).

Granlund, M. and Taipallenmaki, J. (2005) Management control and controllership in new economy firms: A life cycle perspective, Management Accounting Research, 16(1), pp. 21.57.

Heidmann, M. (2008) The role of management accounting systems in strategic sensemaking. (Wiesbaden: Deutscher Universitäts-Verlag).

Henri, J. (2006) Management control systems and strategy: a resource-based perspective, Accounting, Organizations and Society, 31(6), pp. 529-558.

Hermosilla, A. (2001) Factores determinantes de las decisiones de inversión de las multinacionales implantadas en Cataluña. Centre d'Economia Industrial. Universitat Autónoma de Barcelona.

Higgins, J. M. (1996) Innovate or evaporate: creative techniques for strategists, Long Range Planning, 29(3), pp. 370-380.

Hoffman, R.C. and Hegarty, W.H. (1993) Top management influence on innovations: Effects of executive characteristics and social culture, Journal of Management, 19(3), pp. 549-574.

Howells, J. (1995) A socio-cognitive approach towards innovation, Research Policy, 24, pp. 883-894.

Hsu, M. L. A., Chen, M. H. F. and Lin, B. (2008) Top management and organisational innovation: review and future directions, International Journal of Innovation and Learning, 5(5), pp. 533-556.

Humphreys, K. and Cheng, M. (2008) Improving managerial judgments of information relevance and strategy appropriateness using the balanced scorecard and the strategy map, $6^{\text {th }}$ Conference on New Directions in Management Accounting, EIASM Brussels, Belgium, 15-17 December, 2008.

Jansen, K.J. (2004) From persistence to pursuit: a longitudinal examination of momentum during the early stages of strategic change, Organization Science, 15(3), pp. 276-294.

Johanessen, J. A., Olsen, B. and Lumpkin, G. T. (2001) Innovation as newness: what is new, how new and to whom?, European Journal of Innovation Management, 4(1), pp. 20-31.

Kadous, K. and Sedor, L.M. (2004) The efficacy of third-party consultation in preventing managerial escalation of commitment: the role of mental representations, Contemporary Accounting Research, 21(1), pp. 55-82.

Kamm, J. B. (1987) An integrative approach to managing innovation. (Lexington: Lexington Books).

Kanter, R. M. (2001) Evolve! Succeeding in the digital culture of tomorrow. (Boston: Harvard Business School Press).

Kaplan, R. S. and Norton, D. P. (1996) The balanced scorecard. (Boston: Harvard Business School Press).

Kaplan, R. S. and Norton, D. P. (2000) The strategy-focused organization. (Boston: Harvard Business School Press).

Kelly, D. and Amburgey, T.L. (1991) Organisational inertia and momentum: a dynamic model of strategic change,

Academy of Management Journal, 34(3), pp. 591-612.

Langfield-Smith, K. (2007) A Review of Quantitative Research in Management Control Systems and Strategy, in C.S.

Chapman, A.G. Hopwood, and M. D. Shields (Eds) Handbook of management accounting research, pp.753-784 (Oxford: Elsevier).

Leonard-Barton, D. (1995) Wellsprings of knowledge. (Boston: Harvard Business School Press).

Li, H. and Atuahene-Gima, K. (2001) Product innovation strategy and the performance of new technology ventures in China, Academy of Management Journal, 44(6), pp. 1123-1134. 
Word count 13,761

Author's pre-publication proof
To appear in European Accounting Review DOI no: 1031080/09638180902863803

Lichtenhaler, E. (2003) Third Generation Management of Technology Intelligence Processes, R\&D Management, 33(4), pp. 361-375.

Liyanage, S., Greenfield, P. F. and Don, R. (1999) Towards a fourth generation R\&D management model-research networks in knowledge management International, Journal of Technology Management, 18(3/4), pp. 372-393.

Malmi, T. and Brown, D. A. (2008) Management control systems as a package, Opportunities, challenges and research directions, Management Accounting Research, 19 (4), pp. 287-300.

Markman, A.B. and Gentner, D. (2001) Thinking. Annual Review of Psychology, 52, pp. 223-247.

Merchant, K. A. and Van der Stede, W. A. (2007) Management control systems: Performance measurement, evaluation and incentives (2nd edition). (London: Prentice Hall).

Merchant, K. A. and Otley, D. T. (2007) A review of the literature on control and accountability, in C.S. Chapman, A.G. Hopwood, and M. D. Shields (Eds) Handbook of management accounting research, pp.785-804 (Oxford: Elsevier).

Meyer, A. D., Tsui, A. S. and Hinings, C. R. (1993) Configurational approaches to organisational analysis, Academy of Management Journal, 36(6), pp. 1175-1195.

Miller, D. and Friesen, P.H. (1980) Momentum and revolution in organisational adaptation, Academy of management Journal, 23(4), pp. 591-614

Miller, D. and Friesen, P. H. (1982) Innovation in conservative and entrepreneurial firms, Strategic Management Journal, 3(1), pp. 1-25.

Miller, W. and Morris, L. (1999) Fourth Generation R\&D. (New York: John Wiley \& Sons).

Naranjo-Gil, D. and Hartmann, F. (2007) Management accounting systems, top management team heterogeneity and strategic change, Accounting, Organizations and Society, 32(7-8), pp. 735-756.

Neely, A., Kennerley, M. and Adams, C. (2007) Performance measurement frameworks: a review, in Neely, A. (ed.), Business Performance Measurement, pp. 143-162 (Cambridge University Press).

Nieto, M. (2002) From R\&D management to knowledge management: an overview of studies on innovation management, Technological Forecasting and Social Change, 70(2), pp. 135-161.

Nightingale, P. (1998) A cognitive model of innovation, Research Policy, 27(7), pp. 689-709.

OECD (2005) Oslo Manual: Guides for collecting and interpreting innovation data (3rd ed.). OECD/Eurostat.

Otley, D.T. (1980) The contingency theory of management accounting: achievements and prognosis, Accounting, Organizations and Society, 5(4), pp. 413-428.

Otley, D.T. (1999) Performance management: a framework for management control systems research, Management Accounting Research, 10(4), pp. 363-382.

Paraponaris, C. (2003) Third generation R\&D and strategies for knowledge management, Journal of Knowledge Management, 7(5), pp. 96-106.

Park, Y. and Kim, S. (2005) Linkage between knowledge management and R\&D management, Journal of Knowledge Management, 9(4), pp. 34-44.

PMI (Project Management Institute) (2004) Project Management Body of Knowledge. (Newton Sq., PA: Project Management Institute).

Rigby, D. (2001) Management Tools and Techniques: A Survey, California Management Review, 43(2), pp. 139-160.

Rogers, D. M. A. (1996) The challenge of fifth generation R\&D, Research Technology Management, 39(4), pp. 33-41.

Roussel, P. A., Saad, K. N., and Erickson, T. J. (1991) Third Generation R\&D: managing the link to corporate strategy. (Boston: Harvard Business School Press).

Scott, T.W. and Tiessen, P. (1999) Performance measurement and managerial teams, Accounting, Organizations and Society, 24(3), pp. 263-285.

Simons, R. (1991) Strategic orientation and senior management attention to control systems, Strategic Management Journal, 12(1), pp. 49-62.

Simons, R. (1995) Levers of control. (Boston: Harvard Business School Press). 
Word count 13,761

Author's pre-publication proof
To appear in European Accounting Review DOI no: 1031080/09638180902863803

Simons, R. (2000) Performance measurement and control systems for implementing strategies. (Upper Saddle River: Prentice Hall).

Smith, K.G., Collins, C.J. and Clark, K.D. (2005) Existing knowledge, knowledge creation capability and the rate of new product introduction in high technology firms, Academy of Management Journal, 48(2), pp. 346-357.

Souder, W. E. (1987) Managing new product innovation. (Lexington: Lexington Books).

Speckbacher, G., Bischof, J. and Pfeiffer, T. (2003) A descriptive analysis on the implementation of balanced scorecards in German-speaking countries, Management Accounting Research, 14(4), pp.361-388.

Subramaniam and Mia (2003) A note on work-related values, budget emphasis and managers' organisational commitment, Management Accounting Research, 14(4), pp. 389-408.

Teece, D. and Pisano, G. (1994) The dynamic capabilities firms: an introduction, Industrial and Corporation Change, 3(3), pp. 537-555.

Thomas, A. S., Litschert, R. J., and Ramaswamy, K. (1991) The performance impact of strategy-manager coalignment: an empirical examination, Strategic Management Journal, 12(7), pp. 509-522.

Tillema, S. (2005) Towards an integrated contingency framework for MAS sophistication: Case studies on the scope of accounting instruments in Dutch power and gas companies, Management Accounting Research, 16(1), pp. 101-129.

Tuomela, T.S. (2005) The interplay of different levers of control: A case study of introducing a new performance measurement system, Management Accounting Research, 16(3), pp. 293- 320.

Van der Stede, W. A., Young, M. A. and Chen C. X. (2007) Doing Management Accounting Survey Research, in C.S. Chapman, A.G. Hopwood, and M. D. Shields (Eds) Handbook of management accounting research, pp. 445-478 (Oxford: Elsevier).

Van der Veeken, H. J. M. and Wouters, M. J. F. (2002) Using accounting information systems by operations managers in a project company, Management Accounting Research, 13(3), pp. 345-370.

Von Hippel, E. (1988) The Sources of Innovation. (New York: Oxford University Press).

Widener, S.K. (2007) An empirical analysis of the levers of control framework, Accounting, Organizations and Society, 32(7-8), pp. 757-788. 
Word count 13,761

Author's pre-publication proof
To appear in European Accounting Review DOI no: 1031080/09638180902863803

Table 1. Innovation Management Modes and attributes of sophistication (information contents)

\begin{tabular}{|c|c|c|c|c|}
\hline \multirow{2}{*}{$\begin{array}{c}\text { Innovation } \\
\text { Management Modes (IMM) }\end{array}$} & \multicolumn{3}{|c|}{$\begin{array}{l}\text { Attributes of sophistication } \\
\text { (information content) }\end{array}$} & \multirow{2}{*}{$\begin{array}{c}\text { Individual MACS } \\
\text { selected for interactive use }\end{array}$} \\
\hline & Scope & Aggregation & Integration & \\
\hline Intuitive & Broad & Aggregated & High & Balanced Scorecards \\
\hline Systematic & Medium & Disaggregated & Low & Project Management Systems \\
\hline Strategic/Non.expert & Narrow & $\begin{array}{c}\text { Disaggregated } \\
\text { and Aggregated }\end{array}$ & High & Budget Systems \\
\hline Strategic/Expert & $\begin{array}{l}\text { Narrow } \\
\text { or Broad }\end{array}$ & $\begin{array}{l}\text { Disaggregated } \\
\text { and Aggregated }\end{array}$ & High & $\begin{array}{c}\text { Budget Systems } \\
\text { or Balanced Scorecards }\end{array}$ \\
\hline
\end{tabular}

of individual MACS 
Word count 13,761

Author's pre-publication proof
To appear in European Accounting Review DOI no: 1031080/09638180902863803

Panel A

Are ....... present in the firm ?

\begin{tabular}{|c|c|c|c|c|}
\hline $\begin{array}{c}\text { Number of selected MACS } \\
\text { that are present }\end{array}$ & $\begin{array}{c}\text { Budget } \\
\text { Systems }\end{array}$ & $\begin{array}{c}\text { Balanced Scorecards } \\
\text { (BSC) }\end{array}$ & $\begin{array}{c}\text { Project Management Systems } \\
\text { (PMS) }\end{array}$ & Yes \\
\# firms
\end{tabular}

Table 2. Descriptive Statistics of Interactive Use of MACS

\begin{tabular}{|c|c|c|c|c|c|c|c|c|c|}
\hline Panel B & $\begin{array}{c}\text { Theoretical } \\
\text { Range }\end{array}$ & Min & Max & Mean & $\begin{array}{l}\text { Std } \\
\text { Dev }\end{array}$ & Median & \multicolumn{3}{|c|}{$\begin{array}{c}\text { Bivariate Spearman } \\
\text { Correlations }\end{array}$} \\
\hline (1) Interactive Use of Budgets (USEBUD) & $0.00-21.00$ & 0.00 & 19.00 & 12.47 & 4.40 & 13.00 & & $(2)$ & (3) \\
\hline (2) Interactive Use of Balanced Scorecards (USEBSC) & $0.00-21.00$ & 0.00 & 21.00 & 10.94 & 6.42 & 13.00 & $0.432 * *$ & & \\
\hline (3) Interactive Use of Project Mgmt.Systems (USEPMS) & $0.00-21.00$ & 0.00 & 18.00 & 8.05 & 6.70 & 10.00 & $0.351 * *$ & $0.382 * *$ & \\
\hline (4) Innovation (INNOV) & $3.00-21.00$ & 5.00 & 21.00 & 14.12 & 4.45 & 14.00 & -0.224 & 0.117 & -0.013 \\
\hline
\end{tabular}

$\mathrm{n}=57 ; *$, ** Significant levels at $5 \%$ and $1 \%$, respectively (two-tailed tests) 
Word count 13,761

Author's pre-publication proof
To appear in European Accounting Review DOI no: 1031080/09638180902863803

Table 3. Comparison of items scores between clusters

\begin{tabular}{|c|c|c|c|c|c|c|c|c|}
\hline Cluster $^{*}$ & $\mathrm{n}$ & & Allocation & Recognition & Portfolio & Precision & Tech/Buss & Trade-offs \\
\hline \multirow[t]{3}{*}{1} & \multirow[t]{3}{*}{7} & Mean & 4.43 & 4.14 & 2.71 & 5.71 & 3.29 & 3.57 \\
\hline & & Std.Dev. & 1.27 & 1.57 & 0.76 & 0.95 & 1.38 & 1.27 \\
\hline & & Median & 4.00 & 4.00 & 3.00 & 6.00 & 3.00 & 4.00 \\
\hline \multirow[t]{3}{*}{2} & \multirow[t]{3}{*}{8} & Mean & 6.38 & 3.50 & 2.50 & 1.88 & 3.75 & 4.88 \\
\hline & & Std.Dev. & 0.74 & 0.53 & 1.41 & 0.64 & 1.67 & 1.89 \\
\hline & & Median & 6.50 & 3.50 & 2.00 & 2.00 & 4.00 & 5.50 \\
\hline \multirow[t]{3}{*}{3} & \multirow[t]{3}{*}{13} & Mean & 2.38 & 3.46 & 4.00 & 3.77 & 5.15 & 5.38 \\
\hline & & Std.Dev. & 1.04 & 1.13 & 1.53 & 1.59 & 0.99 & 1.04 \\
\hline & & Median & 2.00 & 4.00 & 4.00 & 4.00 & 5.00 & 5.00 \\
\hline \multirow[t]{3}{*}{4} & \multirow[t]{3}{*}{29} & Mean & 6.00 & 5.52 & 5.28 & 3.34 & 6.10 & 5.55 \\
\hline & & Std.Dev. & 0.85 & 1.24 & 1.13 & 1.72 & 0.72 & 1.18 \\
\hline & & Median & 6.00 & 6.00 & 6.00 & 4.00 & 6.00 & 6.00 \\
\hline \multirow[t]{3}{*}{ Total } & \multirow[t]{3}{*}{57} & Mean & 5.04 & 4.60 & 4.28 & 3.53 & 5.21 & 5.18 \\
\hline & & Std.Dev & 1.80 & 1.51 & 1.66 & 1.78 & 1.48 & 1.40 \\
\hline & & Median & 6.00 & 4.00 & 4.00 & 4.00 & 6.00 & 5.00 \\
\hline \multirow{2}{*}{\multicolumn{2}{|c|}{$\begin{array}{l}\text { Kruskal-Wallis test } \\
\qquad(\mathrm{df}=3)\end{array}$}} & Chi-square & 35,808 & 23,704 & 25,667 & 17,354 & 28,980 & 10,483 \\
\hline & & Sig. & .000 & .000 & .000 & .001 & .000 & .015 \\
\hline
\end{tabular}

- 1 = Intuitive; 2 = Systematic; 3 = Strategic/Non-Expert; 4 = Strategic/Expert 
Word count 13,761

Author's pre-publication proof
To appear in European Accounting Review DOI no: 1031080/09638180902863803

Table 4. Interpretation of the clusters representing Innovation Management Modes

\begin{tabular}{|c|c|c|c|c|}
\hline & $\begin{array}{c}\text { Intuitive } \\
(n=7)\end{array}$ & $\begin{array}{l}\text { Systematic } \\
\quad(n=8)\end{array}$ & $\begin{array}{c}\text { Strategic / } \\
\text { Non-expert }(n=13)\end{array}$ & $\begin{array}{c}\text { Strategic / } \\
\text { Expert }(n=29)\end{array}$ \\
\hline $\begin{array}{l}\text { Senior management involvement } \\
\text { in the allocation of resources } \\
\text { to specific projects }\end{array}$ & $\begin{array}{l}\text { Overall } \\
\text { allocation }\end{array}$ & $\begin{array}{l}\text { Allocation to } \\
\text { specific projects }\end{array}$ & $\begin{array}{c}\text { Overall } \\
\text { Allocation }\end{array}$ & $\begin{array}{l}\text { Allocation to specific } \\
\text { projects }\end{array}$ \\
\hline $\begin{array}{l}\text { Role of recognition } \\
\text { of bottom-up blossoming } \\
\text { of innovation initiatives }\end{array}$ & $\begin{array}{l}\text { Non-recognition of } \\
\text { spontaneous } \\
\text { initiatives }\end{array}$ & $\begin{array}{l}\text { Previously } \\
\text { established } \\
\text { framework }\end{array}$ & $\begin{array}{l}\text { Previously established } \\
\text { framework }\end{array}$ & $\begin{array}{c}\text { Framework }+ \\
\text { Recognition of } \\
\text { spontaneous initiatives }\end{array}$ \\
\hline $\begin{array}{c}\text { Extent to which } \\
\text { portfolio techniques are used }\end{array}$ & $\begin{array}{l}\text { Decisions based on } \\
\text { an individual } \\
\text { project-basis }\end{array}$ & $\begin{array}{l}\text { Decisions based on } \\
\text { an individual } \\
\text { project-basis }\end{array}$ & $\begin{array}{l}\text { Decisions based on a } \\
\text { project portfolio-basis }\end{array}$ & $\begin{array}{l}\text { Decisions based on a } \\
\text { project portfolio-basis }\end{array}$ \\
\hline $\begin{array}{c}\text { Level of precision } \\
\text { in project goal-setting } \\
\text { and evaluation of progress }\end{array}$ & Least precise & Most precise & Quite precise & Quite precise \\
\hline $\begin{array}{c}\text { Extent to which } \\
\text { technical and business } \\
\text { perspectives are integrated }\end{array}$ & $\begin{array}{l}\text { Low } \\
\text { integration }\end{array}$ & $\begin{array}{l}\text { Low } \\
\text { integration }\end{array}$ & $\begin{array}{l}\text { Moderate/High } \\
\text { Integration }\end{array}$ & $\begin{array}{l}\text { High } \\
\text { integration }\end{array}$ \\
\hline $\begin{array}{l}\text { Existence of mechanisms } \\
\text { to evaluate trade-offs } \\
\text { among projects }\end{array}$ & $\begin{array}{l}\text { Priorities within } \\
\text { areas }\end{array}$ & $\begin{array}{l}\text { Priorities within } \\
\text { areas }\end{array}$ & Priorities across areas & Priorities across areas \\
\hline
\end{tabular}


Table 5. Medians of construct scores by Innovation Management Mode

\begin{tabular}{|c|c|c|c|c|c|}
\hline & \multirow[b]{2}{*}{$\begin{array}{c}\text { Full } \\
\text { sample } \\
n=57\end{array}$} & \multicolumn{4}{|c|}{ Innovation Management Modes } \\
\hline & & $\begin{array}{c}\text { Intuitive } \\
\mathrm{n}=7\end{array}$ & $\begin{array}{c}\text { Systematic } \\
\mathrm{n}=8 \\
\end{array}$ & $\begin{array}{c}\text { Strategic/ } \\
\text { Non-Expert } \\
n=13 \\
\end{array}$ & $\begin{array}{c}\text { Strategic/ } \\
\text { Expert } \\
n=29\end{array}$ \\
\hline Interactive Use of Budgets (USEBUD) & 13.00 & 8.00 & 12.00 & 15.00 & 13.00 \\
\hline Interactive Use of Balanced Scorecards (USEBSC) & 13.00 & 13.00 & 12.50 & 14.00 & 11.00 \\
\hline Interactive Use of Project Mgmt Systems (USEPMS) & 10.00 & 0.00 & 11.50 & 11.00 & 9.00 \\
\hline Innovation (INNOV) & 14.00 & 14.00 & 15.50 & 13.00 & 15.00 \\
\hline
\end{tabular}

Table 6. Differences between pairs of Interactive Use of individual MACS within Innovation Management Modes ${ }^{\mathrm{a}}$

\begin{tabular}{|c|c|c|c|c|c|}
\hline $\begin{array}{c}\text { Innovation Management Mode } \\
\text { (Hypotheses) }\end{array}$ & \multicolumn{3}{|c|}{$\begin{array}{c}\text { Comparison between Interactive Use } \\
\text { of particular MACS }\end{array}$} & $Z$ & Sign. \\
\hline Intuitive $(\mathrm{Hla})$ & Balanced Scorecards & vs. & Budget Systems & 1.75 & $0.040^{*}$ \\
\hline Intuitive $(H l a)$ & Balanced Scorecards & vs. & Project Management & 2.03 & $0.021 *$ \\
\hline Systematic $(H 1 b)$ & Project Management & vs. & Balanced Scorecards & 0.17 & 0.433 \\
\hline Systematic $(H 1 b)$ & Project Management & vs. & Budget Systems & -1.45 & 0.074 \\
\hline Strategic/non-expert $(H 1 c)$ & Budget Systems & vs. & Balanced Scorecards & 0.71 & 0.238 \\
\hline Strategic/non-expert $(H 1 c)$ & Budget Systems & vs. & Project Management & 2.10 & $0.018^{*}$ \\
\hline Strategic/expert $(H 1 d)$ & Balanced Scorecards & vs. & Project Management & 1.95 & $0.026^{*}$ \\
\hline Strategic/expert $(H I d)$ & Budget Systems & vs. & Project Management & 2.92 & $0.002 * *$ \\
\hline
\end{tabular}

\footnotetext{
${ }^{a}$ Wilcoxon matched-pairs signed-rank test for the median difference of external variables within innovation management modes
} $*, * *$ Significant levels at $5 \%$ and $1 \%$, respectively (one-tailed tests) 
Table 7. Tests for differences on innovation between non-fit and fit firms

Panel A: Mann-Whitney U test for the differences on innovation between non-fit vs. fit in low- and high-innovating firms.

\begin{tabular}{lcc|cc}
\hline & \multicolumn{2}{c|}{ Low-innovating firms } & \multicolumn{2}{c}{ High-innovating firms } \\
\cline { 2 - 5 } & Non-fit & Fit & Non-fit & Fit \\
\cline { 2 - 4 } & $\mathrm{n}=16$ & $\mathrm{n}=15$ & $\mathrm{n}=11$ & $\mathrm{n}=15$ \\
Innovation median & 11.50 & 9.00 & 18.00 & 19.00 \\
$\mathrm{Z}$ & & $-1.716 *$ & & $-1.941^{*}$ \\
\hline
\end{tabular}

*,** Significant levels at $5 \%$ and $1 \%$, respectively (one-tailed tests)

Panel B: Multiple regression of innovation on fit including control variables.

$$
Y=\alpha+\beta_{1} \text { FIT }+\beta_{2} I C S+\beta_{k} I M M \text { dummies }_{k}+\beta_{6} S I Z E+\varepsilon
$$

\begin{tabular}{|c|c|c|c|c|c|c|c|c|}
\hline \multirow[b]{3}{*}{ Constant } & \multicolumn{3}{|c|}{ Low-innovating firms } & & \multicolumn{4}{|c|}{ High-innovating firms } \\
\hline & $\begin{array}{c}\text { Predicted } \\
\text { Sign } \\
\end{array}$ & Coefficient & $\mathrm{t}-\mathrm{Stat}$ & & $\begin{array}{c}\text { Predicted } \\
\text { sign }\end{array}$ & Coefficient & t-Stat & \\
\hline & & & 3.47 & $* *$ & & & 8.31 & $* *$ \\
\hline FIT & + & -0.445 & -1.82 & $*$ & - & 0.502 & 3.34 & $* *$ \\
\hline ICS & & -0.189 & -0.93 & & & -0.444 & -2.83 & $*$ \\
\hline $\mathrm{IMM}_{1}$ & & -0.107 & -0.48 & & & 0.200 & 1.38 & \\
\hline $\mathrm{IMM}_{2}$ & & -0.308 & -1.23 & & & 0.134 & 0.74 & \\
\hline $\mathrm{IMM}_{3}$ & & -0.229 & -0.96 & & & -0.244 & -1.61 & \\
\hline SIZE & & -0.262 & -1.31 & & & 0.056 & 0.34 & \\
\hline $\mathrm{R}^{2}(\mathrm{Adj})$ & & 0.015 & & & & 0.505 & & \\
\hline F-stat & & 1.076 & & & & 5.244 & & $* *$ \\
\hline Max_VIF & & 1.844 & & & & 1.659 & & \\
\hline
\end{tabular}

Dependent variable $=\mathrm{INNOV}^{2}$ for low-innovating firms (to correct for mild negative skewness in this sub-sample); INNOV for high-innovating firms; FIT = Dummy variable that equals 1 if the firm was classified as fit; 0 otherwise; ICS = Interactive use of the individual MACS (USEBUD, USEBSC or USEPMS) that theoretically corresponds to the firm's IMM; IMM = Three dummy variables for the four Innovation Management Modes; SIZE $=\mathrm{Ln}$ (Sales in millions of euros).

*, ** Significant levels at $5 \%$ and $1 \%$, respectively (one-tailed for the variable with predicted sign, two-tailed otherwise). Standardized coefficients are presented for all independent variables. 
Word count 13,761

Author's pre-publication proof
To appear in European Accounting Review DOI no: 1031080/09638180902863803

\footnotetext{
${ }^{1}$ The difference between diagnostic control systems and ICS is not in their technical design features, but solely in the way that managers use these systems. In contrast to diagnostic control systems, ICS are characterised by properties such as an intensive use by senior managers, an intensive use by middle managers, a non-invasive, facilitating and inspirational personal involvement by senior managers, a focus on strategic uncertainties, and the presence of pervasive face-to-face challenges and debate (Simons, 1995; 2000; Bisbe et al., 2007).
}

${ }^{2}$ Ambiguous findings may potentially be explained by differences in the conceptualisation of what constitutes an ICS. If the definitions of what constitutes an ICS include only a narrow subset of its theoretical properties, subsets may vary across studies, and ICS may be mistaken for other constructs such as mere intensive use or mere participative use (Bisbe et al., 2007).

${ }^{3}$ According to the LOC framework, while any individual MACS can potentially be used diagnostically as well as interactively, individual MACS present in the control package of a given firm are used, except in rather exceptional circumstances, either diagnostically or interactively (Simons, 1995, p. 103 and 120; 2000, p. 124 and 208, italics in the original). Nevertheless, some authors (i.e. Tuomela, 2005;Widener, 2007) have pointed out that individual MACS can simultaneously be used both in an interactive and in a diagnostic manner. Based on LOC theory, potential explanations for this discrepancy include the following: 1) the object of analysis covers only one individual MACS, which makes it virtually impossible to comparatively detect diagnostic uses in some individual MACS and interactive uses in other individual MACS; 2) the nature of the MACS under analysis (e.g. performance measurement systems) is too broad (with many subsystems within, some used interactively, some diagnostically); and 3) the conceptualisation of the constitutive properties of ICS is not stringent enough (see Note 2).

${ }^{4}$ Scope of a particular MACS refers to focus and quantification (we have ignored the time horizon subdimension in this study). Narrow (broad) scope MACS provide information that is internally focused and financial (related to both the internal and the external environment and including both financial and nonfinancial measurements). Aggregation refers to the degree to which data is processed and summarised to provide summated information. Hence, low (high) aggregation refers to systems that only provide basic raw, unprocessed data at lower-level units of analysis (systems that provide processed data that is aggregated in higher-level units of analysis). Finally, integration refers to the provision of information as to how the decisions made in one department or area may influence the performance of other departments, areas or activities (Chenhall \& Morris, 1986; Bouwens and Abernethy, 2000).

${ }^{5}$ Hereafter, we use "balanced scorecard" (BSC) to refer to multi-perspective performance measurement systems in generic terms. Therefore, BSC as defined here do not need to follow the exact procedure as suggested by Kaplan and Norton (1996, 2000). For purposes of this study, summarized, multi-perspective sets of both financial and non-financial indicators that aim to capture the extent to which strategic objectives are being achieved, are labelled as BSC.

${ }^{6}$ Organisational and managerial processes refer to the routines, operating principles and patterns of practice within a firm. Rather than modular or loosely-coupled entities that operate in isolation, organisational and managerial processes are better understood as operating in organisational configurations, each configuration representing a coherent multidimensional constellation of conceptually distinct routines, operating principles and patterns of practice (Meyer et al., 1993; Fiss, 2007).

${ }^{7}$ While we extend R\&D and R\&D departments in Roussel et al's framework to innovation and innovative units, we acknowledge that innovation is not necessarily originated or developed within an R\&D department or from R\&D activities (Von Hippel, 1988; Escorsa and Valls, 2003). In fact, studies on technological innovation are experiencing a paradigm shift from R\&D management to knowledge management. Even so, frameworks that link knowledge management, R\&D management and innovation management (e.g. Nieto, 2002; Park and Kim, 2005) have often drawn upon Roussel et al. (1991) typology. Some authors have proposed refinements or extensions of Roussel et al.' s typology (Rogers, 1996; Liyanage et al., 1999; Miller and Morris, 1999; Park and Kim, 2005), but consensus regarding these adaptations, and consequently their influence, is still limited.

${ }^{8}$ Even though typologies of R\&D modes and IMM can be interpreted as chronologies of generations associated to specific periods of time in an evolutionary process, they can be alternatively interpreted as maps of configurations which can co-exist at a given moment in time across firms that follow different organisational 
patterns. For example, consistent with this latter approach, Roussel et al. (1991, p. 25) point out that "as we look on today's industrial scene, we see [the] three generations of R\&D management in practice". In this study, we adopt this latter approach, and therefore expect the different IMM to coexist contemporarily in the industrial setting.

${ }^{9}$ In order to control for undesired effects related to relationships with headquarters, subsidiaries of multinational companies (MNC) with headquarters outside Spain were excluded, since most often these companies do not locate research centres and innovation activities in Spain. Even though there are some significant exceptions, most Spanish subsidiaries of MNC headquartered outside Spain engage in advanced manufacturing or commercial activities related to innovative advanced products developed abroad rather than developing their own innovations (Buesa and Molero, 1998; Hermosilla, 2001).

10 The firms in the resulting useable sample represent a variety of industries, including chemical and pharmaceutical (11 firms), textile ( 7 firms), food and beverages (6 firms), manufacturing of mechanical equipment (6 firms), metal manufacturing (6 firms), manufacturing of electrical equipment (5 firms), automobile supplies and parts (4 firms) and miscellaneous (12 firms). Average sales are €57.5 million (minimum $€ 18.63$, maximum $€ 165.28$ million) and the average number of employees is 386 (minimum 204, maximum 800).

11 Hierarchical agglomerative techniques using Ward's method indicated similar percentage changes in the agglomeration coefficient across the relevant range of number of clusters. Visual inspection of the dendrograms did not provide either a clear-cut basis for selecting a number of clusters to be formed. Therefore, cluster centroids from the hierarchical results for 2, 3, 4 and 5 clusters were respectively used as initial seed points for the respective non-hierarchical clustering procedures. The four-cluster solution was selected since it was consistent with the results of the analysis and was theoretically interpretable. In order to test robustness, we engaged in a two-step sensitivity analysis. First, we ran six alternative hierarchical clustering procedures excluding one of the six variables used to form the clusters at a time. Based on the agglomeration coefficients and the dendrograms, in 5 out of 6 computations the four-cluster solution surfaced as appropriate and was theoretically interpretable. Second, we replicated the non-hierarchical procedures (prespecifying four clusters) with subsamples resulting from a random split. We evaluated the congruence between the assignment of observations to clusters using the randomly split subsamples and the assignment to clusters in the full-sample solution, obtaining $74 \%$ coincidence in the assignment of observations to clusters $(\mathrm{Z}=3.56$; $\mathrm{p}<0,001)$.

${ }^{12}$ IMMs and ICS have different natures. While IMM represent a limited number of equilibrium states that are largely path-dependant (Roussel et al., 1991; Park and Kim, 2005), the interactive use of a particular MACS can be adjusted or fine-tuned incrementally in a continuous progression (Simons, 1995). Consequently, we ruled out a configuration approach to fit and the predicted association between IMM and ICS is specified as a Cartesian fit (Gerdin and Greve, 2004, 2008) 